\title{
Spatial and temporal occurrence of fin whales (Balaenoptera physalus) and euphausiids (Nyctiphanes simplex) in the Ballenas Channel, Gulf of California, Mexico
}

\section{Variación espaciotemporal de la distribución de rorcuales comunes (Balaenoptera physalus) y eufáusidos (Nyctiphanes simplex) en el canal de Ballenas, golfo de California, México}

\author{
Paloma Ladrón-de-Guevara, Gisela Heckel*, Bertha E Lavaniegos \\ Centro de Investigación Científica y de Educación Superior de Ensenada, Carretera Ensenada-Tijuana 3918, \\ Zona Playitas, 22860 Ensenada, Baja California, Mexico \\ * Corresponding author. E-mail: gheckel@cicese.mx
}

\begin{abstract}
Fin whales (Balaenoptera physalus) are observed year-round in the Ballenas Channel and Bahía de los Ángeles region, Gulf of California, where their main food item is the euphausiid Nyctiphanes simplex. This investigation was designed under the hypothesis that the spatial and temporal occurrence of whales and euphausiids coincides. The aim was to establish the geographic, seasonal, and interannual changes in the abundance of the fin whale and its main prey in the region during 2003 and 2004. Four field trips were carried out per year. Surveys to search for whales and carry out horizontal surface tows were conducted from small boats. Fin whales and euphausiids were mainly observed off the coast of Baja California and in the southern Ballenas Channel. Their abundance varied significantly from one season to another in both years. The highest relative abundance of whales occurred in July (warm season), followed by June (cold-warm transition period) and March-April (cold season), and the lowest in October (late warm season). Euphausiid abundance was significantly higher in June (cold--warm transition period), followed by July (warm season). There was no direct correlation between weekly abundances of both species, probably because whale peak abundance occurred four weeks later than euphausiid peak abundance. Fin whale relative abundance was significantly higher in 2004 than in 2003 (2.22 and 0.46 whales $\mathrm{h}^{-1}$, respectively), but euphausiid abundance remained almost the same (geometric means 255 and $174 \mathrm{ind} / 1000 \mathrm{~m}^{3}$ ). Even though there was no weekly correlation between both species, their geographic distribution did overlap.
\end{abstract}

Key words: Balaenoptera physalus, fin whale, Nyctiphanes simplex, euphausiids, Gulf of California.

RESUMEN. El rorcual común (Balaenoptera physalus) se observa durante todo el año en la región del canal de Ballenas y bahía de los Ángeles, donde su presa principal es el eufáusido Nyctiphanes simplex. Esta investigación se diseñó bajo la hipótesis de que coincide la distribución espacial y temporal de los rorcuales y los eufáusidos. El objetivo fue establecer las variaciones geográficas, estacionales e interanuales de la abundancia del rorcual común y su principal presa en esta región en 2003 y 2004. Se llevaron a cabo cuatro salidas de campo al año. Los recorridos para buscar ballenas y hacer arrastres superficiales se realizaron en embarcaciones menores. Los rorcuales comunes y los eufáusidos se observaron principalmente frente a la costa de Baja California y al sur del canal de Ballenas. La abundancia de rorcuales y eufáusidos varió estacionalmente en forma significativa en ambos años. La mayor abundancia relativa de rorcuales ocurrió en julio (temporada cálida), seguida de junio (periodo de transición frío a cálido) y marzo-abril (temporada fría), y la más baja ocurrió en octubre (temporada cálida tardía). La abundancia de eufáusidos fue significativamente más alta en junio (periodo de transición frío a cálido), seguida de julio (temporada cálida). No hubo una correlación directa en la abundancia semanal de ambas especies, probablemente porque el máximo de abundancia de ballenas ocurrió cuatro semanas después del máximo de abundancia de eufáusidos. La abundancia relativa del rorcual común fue significativamente mayor en 2004 que en 2003 ( 2.22 y 0.46 ballenas $\mathrm{h}^{-1}$, respectivamente) pero la abundancia de eufáusidos fue casi la misma (medias geométricas 255 y 174 ind $/ 1000 \mathrm{~m}^{3}$ ). Aunque no hubo una correlación entre la abundancia semanal de ambas especies, sí se encontró que coincidieron espacialmente.

Palabras clave: Balaenoptera physalus, rorcual común, Nyctiphanes simplex, eufáusidos, golfo de California.

\section{INTRODUCTION}

Like other rorqual species (Balaenopteridae), fin whales (Balaenoptera physalus) use lunge feeding as their strategy to capture their prey (Croll et al. 2009). They are capable of engulfing $71 \mathrm{~m}^{3}$ of water, a volume larger than that of the whale's entire body (Goldbogen et al. 2007). This enables

\section{INTRODUCCIÓN}

Al igual que otras especies de rorcuales (Balaenopteridae), el rorcual común (Balaenoptera physalus) utiliza la estrategia de alimentación conocida como "embestida" para capturar su presa (Croll et al. 2009). Es capaz de ingerir $71 \mathrm{~m}^{3}$ de agua, un volumen mayor que el de su cuerpo entero 
them to prey on copepods, fish, and squid, although their most frequent prey are euphausiids (Kawamura 1982). Furthermore, when fish (e.g., the sardine Sardinops sagax and thread herring Opisthonema libertate, Tershy et al. 1993) and euphausiids (Nyctiphanes simplex) are found in the same area, fin whales prefer to forage on the latter (Tershy et al. 1993). In the Gulf of California, even though this rorqual has been observed foraging on euphausiids and fishes (AcevedoGutiérrez et al. 2002), scat analyses showed that $75 \%$ of hard remains were from N. simplex (Del-Ángel-Rodríguez 1997), one of the two most abundant species of euphausiids in this area (Brinton and Townsend 1980).

The fin whale's distribution in the Gulf of California, as that of other baleen whales, is related to upwelling and strong mixing zones that sustain high biological productivity (Vidal et al. 1993). Fin whales are commonly found during the cold season (December-May) in the southern gulf and their abundance decreases during the warm season (July-October) (Flores-Ramírez et al. 1996, Alonso-Lozano 2014), probably due to the low availability of their main prey ( $N$. simplex) (Gómez-Gutiérrez et al. 2010). During the warm season, fin whales can be found mainly in the northern gulf (EnríquezParedes 1996), probably due to the high biomass of $N$. simplex to the south of the Midriff Islands region (GómezGutiérrez et al. 2012). The seasonal movement of fin whales to the northern gulf has been confirmed with satellite tags deployed on 11 fin whales from La Paz Bay in March 2001. Three of the tagged whales moved to the Midriff Islands region during the warm season, when chlorophyll concentrations were higher compared to other areas within the Gulf of California (Urbán-Ramírez et al. 2005).

Since the abundance of fin whales varies from season to season in different regions of the Gulf of California, more thorough research is necessary to determine whether these variations are related to prey availability. The Ballenas Channel has been described as a very productive region (Álvarez-Molina et al. 2013) and relevant to the fin whale's foraging ecology (Tershy et al. 1993). During the collection of this study's data, we observed fin whales foraging on daytime surface swarms of $N$. simplex (18 sightings) in shallow waters (10-100 m) off the west and south coast of Coronado Island from March to early August 2003 and 2004 (Ladrón de Guevara et al. 2008). Here, we present the systematic and quantitative analysis of the geographic and seasonal changes during two years (2003 and 2004) in the abundance of the fin whale and its main prey in the Ballenas Channel and Bahía de los Ángeles region in the northwestern Gulf of California. This information is important from an ecological perspective to better understand the variability in the abundance of B. physalus and the significance of euphausiid availability to the foraging ecology of this whale, since fin whales prey both on fish and euphausiids, but they seem to prefer one or the other in different regions in the gulf and during different seasons (Jaume-Schinkel 2004).
(Goldbogen et al. 2007). Esto le permite atrapar copépodos, peces y calamares, aunque los eufáusidos son su presa principal (Kawamura 1982). De hecho, cuando se encuentran peces (e.g., Sardinops sagax y Opisthonema libertate, Tershy et al. 1993) y eufáusidos (Nyctiphanes simplex) en la misma zona, el rorcual común prefiere alimentarse de eufáusidos (Tershy et al. 1993). En el golfo de California, a pesar de que el rorcual común ha sido observado alimentándose de eufáusidos y peces (Acevedo-Gutiérrez et al. 2002), un análisis de heces mostró que $75 \%$ de los restos duros eran de $N$. simplex (Del-Ángel-Rodríguez 1997), una de las dos especies de eufáusidos más abundantes de la región (Brinton y Townsend 1980).

La distribución del rorcual común en el golfo de California, como la de otras ballenas barbadas, está relacionada con zonas de mezcla y de surgencias que sostienen una alta productividad biológica (Vidal et al. 1993). En la región sur del golfo, comúnmente se encuentra durante la temporada fría (diciembre a mayo), y su abundancia disminuye durante la temporada cálida (julio a octubre) (Flores-Ramírez et al. 1996, Alonso-Lozano 2014) probablemente debido a la poca disponibilidad de su presa principal (N. simplex) (GómezGutiérrez et al. 2010). Durante la temporada cálida, el rorcual común se observa principalmente en la región norte del golfo (Enríquez-Paredes 1996), probablemente debido a la alta biomasa de $N$. simplex al sur de la región de las grandes islas (Gómez-Gutiérrez et al. 2012). Se ha confirmado el movimiento estacional de esta especie hacia la parte norte del golfo mediante la colocación de rastreadores satelitales en 11 individuos de la bahía de La Paz en marzo de 2001. Tres de ellos se trasladaron a la región de las grandes islas durante la temporada cálida, cuando las concentraciones de clorofila son mayores que en otras zonas del golfo de California (Urbán-Ramírez et al. 2005).

Puesto que la abundancia del rorcual común varía entre temporadas en las diferentes regiones del golfo de California, se requieren más estudios para comprobar si estas variaciones se relacionan con la disponibilidad de presas. El canal de Ballenas ha sido descrito como una región muy productiva (Álvarez-Molina et al. 2013) y relevante para la ecología alimentaria del rorcual común (Tershy et al. 1993). Durante la recolección de los datos para este estudio, se observaron individuos de esta especie alimentándose de enjambres superficiales de $N$. simplex durante el día (18 avistamientos) en aguas someras $(10-100 \mathrm{~m})$ al oeste y sur de la isla Coronado entre marzo y agosto de 2003 y 2004 (Ladrón de Guevara et al. 2008). Aquí, presentamos un análisis sistemático y cuantitativo de los cambios geográficos y estacionales durante dos años (2003 y 2004) de la abundancia del rorcual común y su presa principal en la región del canal de Ballenas y la bahía de los Ángeles en el golfo de California noroccidental. Desde una perspectiva ecológica, esta información es importante para un mejor conocimiento de la variabilidad de la abundancia de $B$. physalus y la importancia de la disponibilidad de eufáusidos para la 


\section{MATERIALS AND METHODS}

\section{Field work}

Ballenas Channel and Bahía de los Ángeles are located in the northwestern Gulf of California (fig. 1). Due to constant upwelling and tidal mixing, this channel has the lowest sea surface temperature year-round (López et al. 2006) and the highest biological productivity in the gulf (Álvarez-Borrego and Lara-Lara 1991, Gómez-Gutiérrez et al. 2012, Escalante et al. 2013). Moreover, methane concentrations and sea-air methane fluxes were found to be highest in Ballenas Channel in a study of the northern gulf by Macías-Zamora et al. 2013; these authors state that this may be due to biological methane production in the water column, most likely in zooplankton guts. According to oceanographic and climatic conditions, and primary productivity, seasonal changes indicate a warm (July-October) and a cold (December-May) season, as well as two short transition periods, one in June and one in

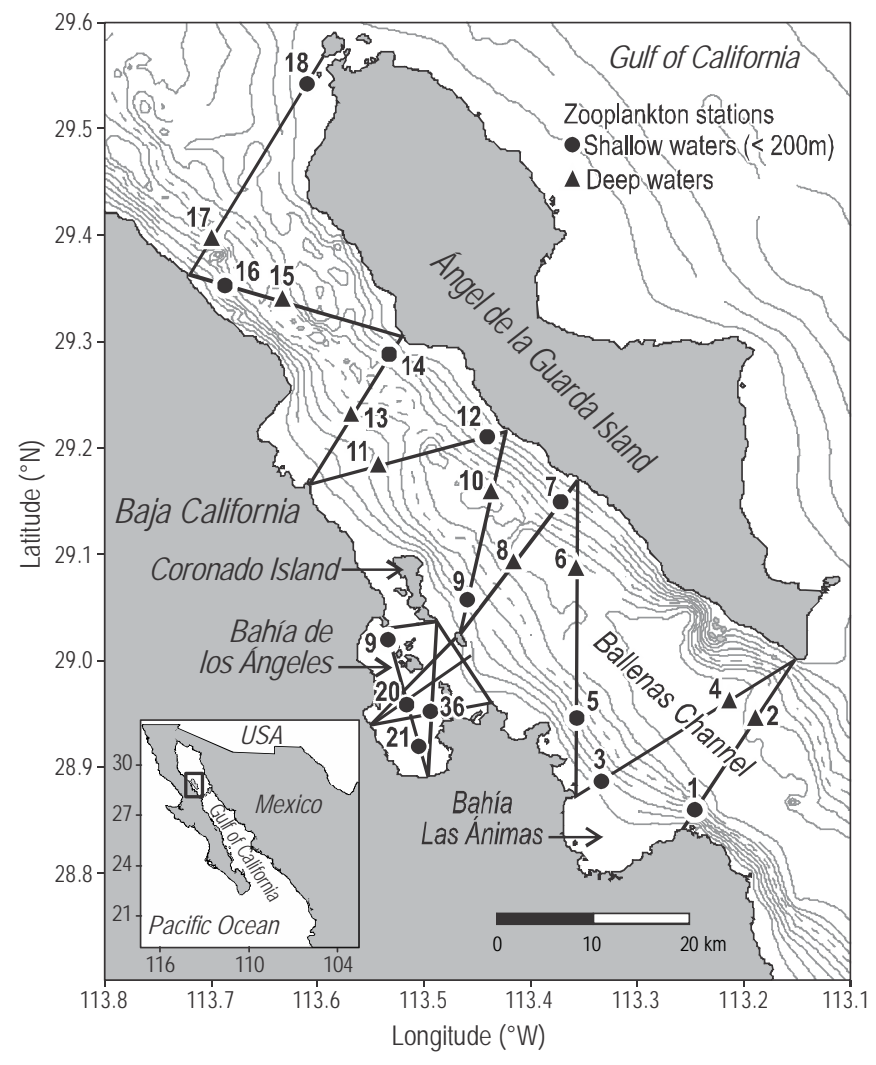

Figure 1. Map of the study area (Ballenas Channel and Bahía de los Ángeles) in the northwestern Gulf of California, Mexico, showing the survey plan (line transects) used to search for cetaceans, the zooplankton sampling stations (symbols), and the bathymetry (isobath interval is $100 \mathrm{~m}$ ).

Figura 1. Mapa del área de estudio (canal de Ballenas y bahía de los Ángeles) en el golfo de California noroccidental, México, que muestra la red de muestreo (transectos) diseñada para buscar cetáceos, las estaciones de muestreo de zooplancton (símbolos) y la batimetría (intervalo de las isóbatas $=100 \mathrm{~m}$ ). ecología alimentaria de esta especie, ya que sus presas son tanto peces como eufáusidos, pero parece tener ciertas preferencias por unos $\mathrm{u}$ otros en diferentes regiones del golfo $\mathrm{y}$ durante diferentes temporadas (Jaume-Schinkel 2004).

\section{MATERIALES Y MÉTODOS}

\section{Trabajo de campo}

El canal de Ballenas y la bahía de los Ángeles se localizan en la parte noroccidental del golfo de California (fig. 1). A causa de la constante surgencia y mezcla por mareas, este canal presenta la menor temperatura superficial del mar a lo largo del año (López et al. 2006) así como la mayor productividad biológica del golfo (Álvarez-Borrego y Lara-Lara 1991, Gómez-Gutiérrez et al. 2012, Escalante et al. 2013). Además, en un estudio en la región norte del golfo, MacíasZamora et al. (2013) encontraron que las concentraciones de metano y los flujos de metano entre el mar y la atmósfera eran mayores en el canal de Ballenas (Macías-Zamora et al. 2013), y lo atribuyeron a la producción biológica de metano en la columna de agua, probablemente en los intestinos de zooplancton. Con base en las condiciones oceanográficas y climáticas y la productividad primaria, los cambios estacionales abarcan una temporada cálida (julio a octubre) y una temporada fría (diciembre a mayo), así como dos periodos cortos de transición, uno en junio y otro en noviembre (Álvarez-Borrego y Lara-Lara 1991, Hidalgo-González y Álvarez-Borrego 2004).

Los muestreos en el área de estudio se realizaron durante cuatro periodos estacionales en 2003 (frío, 12 de marzo a 10 de abril; transición de frío a cálido, 27 de mayo a 26 de junio; cálido, 11 de julio a 4 de agosto; y cálido tardío, 16 de octubre a 2 de diciembre) y durante cuatro periodos en 2004 (frío, 6-31 de marzo; transición de frío a cálido, 3 de junio a 1 de julio; cálido, 2-30 de julio; y cálido tardío, 7-31 de octubre). Los recorridos para buscar rorcuales y recolectar eufáusidos mediante arrastres superficiales se realizaron a bordo de embarcaciones menores (6 $\mathrm{m}$ de eslora) de acuerdo con una red de muestreo establecida (fig. 1).

Los recorridos se planearon para evaluar la distribución del rorcual común en el área de estudio mediante el método de muestreo por distancia (Buckland et al. 2001). Se navegó a lo largo de las líneas de transecto (fig. 1) a una velocidad de 14-16 km h${ }^{-1}$ (Barlow y Forney 2007), mientras cinco observadores buscaban ballenas del lado izquierdo y derecho $\left(90^{\circ}\right)$ y enfrente de la embarcación con binoculares de $7 \times 50$. Para analizar la variación temporal de la abundancia del rorcual común, se incorporaron datos de muestreos no sistemáticos adicionales. Éstos se realizaron a velocidades de 16-30 $\mathrm{km} \mathrm{h}^{-1}$ y sólo cuando se contaba con uno o dos observadores, cuando las condiciones del viento y mar no permitían terminar un transecto, o durante el recorrido entre nuestra base (bahía de los Ángeles) y el punto inicial o final de un transecto. 
November (Álvarez-Borrego and Lara-Lara 1991, HidalgoGonzález and Álvarez-Borrego 2004).

We visited the study area during four seasonal periods in 2003 (cold, 12 March to 10 April; cold-warm transition, 27 May to 26 June; warm, 11 July to 4 August; and late warm, 16 October to 2 December) and four periods in 2004 (cold, 6-31 March; cold-warm transition, 3 June to 1 July; warm, 2-30 July; and late warm, 7-31 October). We used small boats (6 $\mathrm{m}$ long) to navigate in search for fin whales and to carry out surface net tows collecting euphausiids in a fixed sampling grid (fig. 1).

Surveys were planned to assess the distribution of fin whales in the study area and distance sampling methods were applied (Buckland et al. 2001). We navigated along line transects (fig. 1) at $14-16 \mathrm{~km} \mathrm{~h}^{-1}$ (Barlow and Forney 2007), with a team of five observers searching the areas $90^{\circ}$ to the left and right, and in front of the boat with $7 \times 50$ binoculars. In order to analyze the temporal variation of fin whale abundance, data from additional, non-systematic surveys were included. These were carried out at speeds of $16-30 \mathrm{~km} \mathrm{~h}^{-1}$ and only when one or two observers were available, when wind and sea conditions did not permit finishing a transect, or during navigations between our base station (Bahía de los Ángeles) and the start or endpoint of a transect.

Combining both survey years, we navigated for 70 days, with a mean search effort ( \pm SD) of $3.6 \pm 1.4 \mathrm{~h} \mathrm{~d}^{-1}$ in 2003 and $3.2 \pm 1.6 \mathrm{~h} \mathrm{~d}^{-1}$ in 2004. The search effort was defined as the time spent and distance covered while actively looking for whales: $104 \mathrm{~h}(1463 \mathrm{~km})$ and $91 \mathrm{~h}(1450 \mathrm{~km})$ along transects in 2003 and 2004, respectively; $150 \mathrm{~h}(3193 \mathrm{~km})$ and $138 \mathrm{~h}(3184 \mathrm{~km})$ in non-systematic surveys in 2003 and 2004, respectively.

Euphausiids were collected by horizontal surface net tows with a conical net (diameter $50 \mathrm{~cm}$, mesh size $200 \mu \mathrm{m}$ ) at previously defined stations. Two stations on each line transect were selected (fig. 1): one in shallow waters $(<200 \mathrm{~m}$ bottom depth) and one in deep waters (201-1400 m). Towing distance was measured with a GPS and tows were carried out at a speed of $5 \mathrm{~km} \mathrm{~h}^{-1}$ during $5 \pm 1$ min $($ mean $\pm \mathrm{SD}$ ). This towing time was determined as being representative since longer tows often clogged the net. Net size and time of tow were used to calculate the volume of water filtered during each tow. Mean filtered water $( \pm \mathrm{SD})$ was $79 \pm 19 \mathrm{~m}^{3}$. Samples were preserved in $4 \%$ formaldehyde buffered with sodium borate. Fifty-four zooplankton samples were collected in 2003 and 77 in 2004.

At each zooplankton station sea surface temperature (SST) was recorded with a bucket thermometer. We also used satellite SST data downloaded from NASA's OceanColor Web (http://oceancolor.gsfc.nasa.gov).

\section{Sample and data analyses}

To analyze fin whale distribution we only used data from line transects since this sampling method does not bias
Combinando los dos años, navegamos durante 70 días, con un esfuerzo de búsqueda (media $\pm \mathrm{DE}$ ) de $3.6 \pm 1.4 \mathrm{~h} \mathrm{~d}^{-1}$ en 2003 y $3.2 \pm 1.6 \mathrm{~h} \mathrm{~d}^{-1}$ en 2004 . El esfuerzo de búsqueda se definió como el tiempo transcurrido y la distancia recorrida durante la búsqueda activa de ballenas: $104 \mathrm{~h}(1463 \mathrm{~km})$ y $91 \mathrm{~h}(1450 \mathrm{~km})$ en los transectos en 2003 y 2004, respectivamente; y $150 \mathrm{~h}(3193 \mathrm{~km})$ y $138 \mathrm{~h}(3184 \mathrm{~km})$ en los muestreos no sistemáticos de 2003 y 2004, respectivamente.

Los eufáusidos se recolectaron realizando arrastres superficiales con una red cónica (diámetro de $50 \mathrm{~cm}$, tamaño de luz de malla de $200 \mu \mathrm{m}$ ) en estaciones definidas previamente. Se seleccionaron dos estaciones en cada transecto (fig. 1): una en aguas someras ( $<200 \mathrm{~m}$ de profundidad) y otra en aguas profundas (201-1400 m de profundidad). Los arrastres (distancia medida con GPS) se realizaron a una velocidad de $5 \mathrm{~km} \mathrm{~h}^{-1}$ durante $5 \pm 1$ min (media $\pm \mathrm{DE}$ ). Este tiempo de duración del arrastre se consideró como representativo ya que la red frecuentemente se atascaba durante los arrastres más largos. El tamaño de la red y el tiempo de arrastre fueron usados para calcular el volumen de agua filtrada durante cada arrastre, que en promedio fue $79 \pm 19 \mathrm{~m}^{3}$ (media $\pm \mathrm{DE}$ ). Las muestras se preservaron en formaldehído al $4 \%$ amortiguado con borato de sodio. Se recolectaron 54 y 77 muestras de zooplancton en 2003 y 2004, respectivamente.

En cada estación de muestreo se registró la temperatura superficial del mar (TSM) con un termómetro de cubeta. También se usaron datos satelitales de TSM proporcionados por la NASA (http://oceancolor.gsfc.nasa.gov).

\section{Análisis de muestras y datos}

Para analizar la distribución de B. physalus se usaron sólo los datos obtenidos a lo largo de los transectos ya que este método de muestreo no sesga los avistamientos a alguna zona en particular (fig. 1) (Buckland et al. 2001). Se calculó un índice de abundancia relativa (IAR, número de ballenas por kilómetro de esfuerzo de búsqueda), y se compararon los IAR promedio para aguas someras $(0-200 \mathrm{~m})$ y profundas (201-1400 m). La isóbata de $200 \mathrm{~m}$ representa el borde de la plataforma continental, donde la comunidad de zooplancton es dominada por unas cuantas especies, entre ellas $N$. simplex, por lo que se esperaría encontrar un mayor número de rorcuales. No se encontraron diferencias significativas en los IAR semanales tanto de los transectos como de los muestreos no sistemáticos $\left(t_{69}=-0.66, P=0.87\right)$; por lo tanto, se combinaron estos datos para incrementar el tamaño de muestra y evaluar la variación temporal de la abundancia del rorcual común. Se usaron pruebas no paramétricas para realizar las comparaciones estadísticas de los datos semanales, estacionales y anuales (Neave y Worthington 1988).

Las muestras de zooplancton fueron fraccionadas (de $1 / 16$ a 1/64) con un fraccionador de plancton Folsom dependiendo de la cantidad de plancton. Las especies de eufáusidos 
sightings to any particular area (fig. 1) (Buckland et al. 2001). We calculated a relative abundance index (RAI, number of whales per kilometer of search effort) and compared the mean RAI for shallow $(0-200 \mathrm{~m})$ and deep (201-1400 m) waters. The 200-m-isobath is the edge of the continental shelf, where the zooplankton community is dominated by few species, one of them N. simplex, and we would therefore expect to find more whales in shallow waters. There were no significant differences in the weekly RAI from both transects and non-systematic surveys $\left(t_{69}=-0.66\right.$, $P=0.87$ ); therefore, we pooled these data to assess the temporal variation in the abundance of fin whales to increase sample size. We used nonparametric tests for the weekly, seasonal, and yearly statistical comparisons (Neave and Worthington 1988).

Zooplankton samples were subsampled (1/16 to $1 / 64)$ with a Folsom plankton splitter depending on the amount of plankton. Euphausiid species were identified and counted according to life phases: calyptopis, furcilia, juveniles, and adults (Boden 1951). Euphausiid abundance was standardized to the number of individuals per 1000 cubic meters. Again, nonparametric tests were used for the weekly, seasonal, and yearly abundance comparisons.

Since a correlation between euphausiids and whales was attempted, the population structure of euphausiids was analyzed because daytime surface net tows tend to collect more larval (calyptopis and furcilia) than postlarval stages (juveniles and subadults). Euphausiid abundance was converted to carbon biomass using an equation for Euphausia pacifica (Ross 1982):

$$
y=0.337(x)^{3.17}
$$

where $y$ is carbon biomass $(\mu \mathrm{g})$ and $x$ is body length $(\mathrm{mm})$.

This equation was applied to all life phases of $N$. simplex assuming the mean body length of calyptopis $(2 \mathrm{~mm})$, furcilia $(4.5 \mathrm{~mm})$, juveniles $(6.5 \mathrm{~mm})$, and adults $(12 \mathrm{~mm})$. We used the equation for $E$. pacifica because there is no equation available for $N$. simplex. To analyze the possible correlation between the weekly relative abundance of whales and the biomass of euphausiids, we applied the nonparametric Spearman correlation test.

We also compared mean SST between 2003 and 2004, both for data recorded in situ during surveys and weekly mean SST from satellite data.

\section{RESULTS}

\section{Sea surface temperature (SST)}

Mean SST $\pm \mathrm{SD}$ in $2003\left(25.2 \pm 3.3^{\circ} \mathrm{C}\right)$, measured in situ, was significantly higher than in $2004\left(23 \pm 4.1^{\circ} \mathrm{C} ; t_{548}=6.44\right.$, $P<0.001$ ). Seasonal temperature variations were high since the difference between March and October was $2^{\circ} \mathrm{C}$, compared with an interannual difference of $1.5^{\circ} \mathrm{C}$ (fig. 2a). se identificaron y contaron según sus etapas de vida: caliptopis, furcilia, juveniles y adultos (Boden 1951). Se estandarizó la abundancia de eufáusidos al número de individuos por 1000 metros cúbicos. De nuevo, se usaron pruebas no paramétricas para las comparaciones semanales, estacionales y anuales.

Puesto que se intentó determinar si existía una correlación entre eufáusidos y rorcuales, se analizó la estructura de la población de eufáusidos porque los arrastres superficiales durante el día tienden a recolectar un mayor número de eufáusidos en etapas larvales (caliptopis y furcilia) que en etapas postlarvales (juveniles y subadultos). La abundancia de eufáusidos se convirtió en biomasa de carbono mediante la ecuación para Euphausia pacifica (Ross 1982):

$$
y=0.337(x)^{3.17}
$$

donde $y$ es la biomasa de carbono $(\mu \mathrm{g})$ y $x$ es la longitud corporal (mm).

Esta ecuación se aplicó a todas las etapas de vida de $N$. simplex suponiendo la longitud corporal promedio de caliptopis $(2 \mathrm{~mm})$, furcilia $(4.5 \mathrm{~mm})$, juveniles $(6.5 \mathrm{~mm}) \mathrm{y}$ adultos $(12 \mathrm{~mm})$. Se usó la ecuación para E. pacifica porque no hay una ecuación para $N$. simplex. Para analizar la posible correlación entre la abundancia relativa semanal del rorcual común y la biomasa de eufáusidos, se aplicó la prueba de correlación no paramétrica de Spearman.

También se comparó la TSM entre 2003 y 2004, tanto para los datos registrados in situ como para la TSM media semanal de los datos satelitales.

\section{RESUltados}

\section{Temperatura superficial del mar (TSM)}

La TSM media ( $\pm \mathrm{DE})$, medida in situ, fue signitivamente mayor en $2003\left(25.2 \pm 3.3{ }^{\circ} \mathrm{C}\right)$ que en $2004\left(23 \pm 4.1^{\circ} \mathrm{C}\right.$; $\left.t_{548}=6.44, P<0.001\right)$. Las variaciones estacionales de temperatura fueron altas ya que la diferencia entre marzo y octubre fue de $2^{\circ} \mathrm{C}$, en comparación con una diferencia interanual de $1.5^{\circ} \mathrm{C}$ (fig. 2a). Los datos satelitales subestimaron los datos reales de TSM pero mostraron una tendencia similar a la de los datos in situ, siendo mayor en 2003 $\left(23.3 \pm 4.8^{\circ} \mathrm{C}\right)$ que en $2004\left(22.5 \pm 4.9^{\circ} \mathrm{C}\right)$, aunque no se observaron diferencias significativas entre años $\left(t_{88}=0.755\right.$, $P=0.45$ ). Esto se puede deber a que la TSM fue similar de junio a septiembre (fig. 2b). Los datos satelitales, sin embargo, mostraron una diferencia de $1.0^{\circ} \mathrm{C}$ entre marzo de 2003 y 2004, y de $1.6^{\circ} \mathrm{C}$ entre octubre de 2003 y 2004.

\section{Distribución del rorcual común y eufáusidos}

El esfuerzo de búsqueda de rorcuales no mostró diferencias significativas entre años en el caso de los transectos 


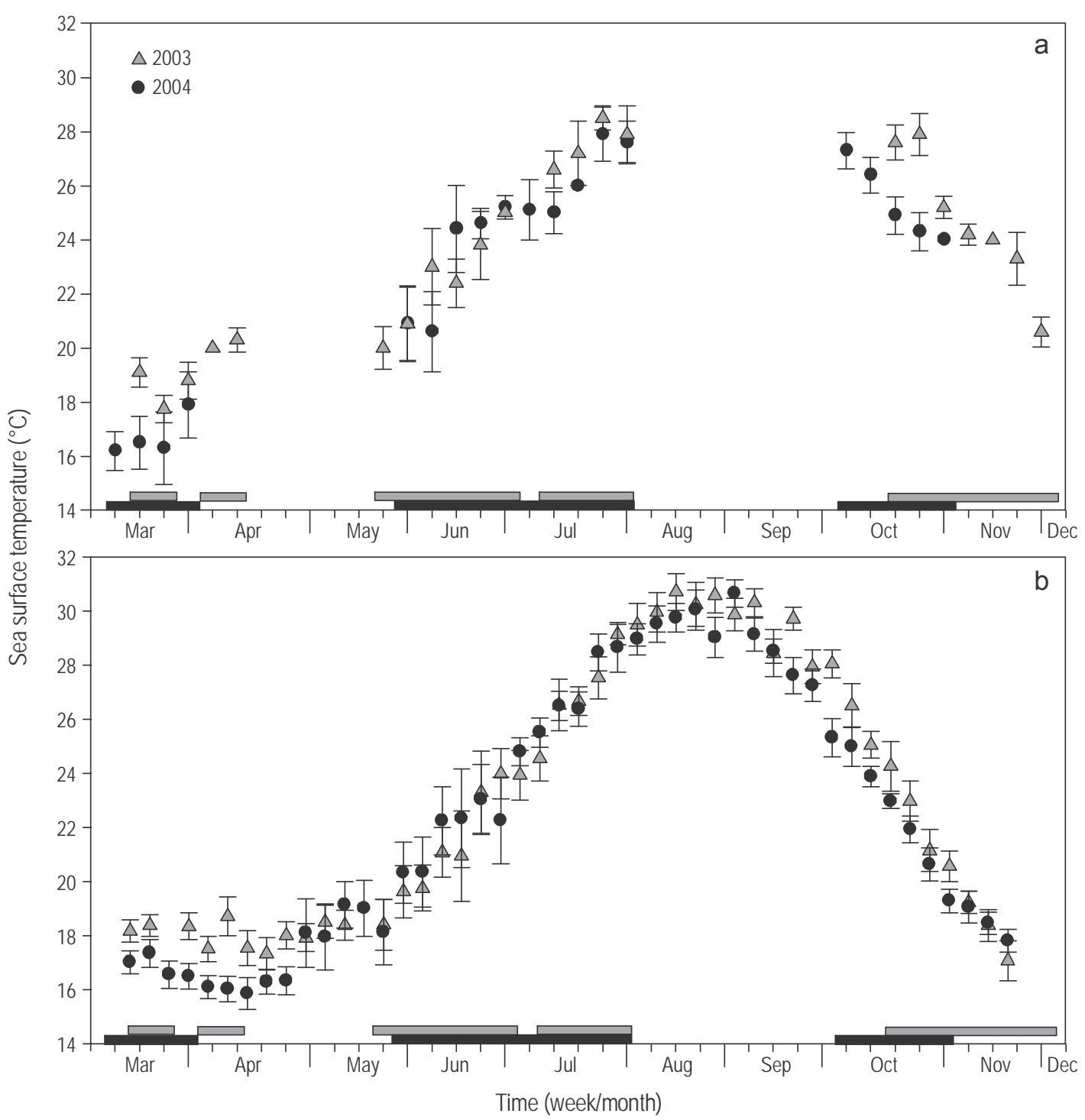

Figure 2. Weekly mean sea surface temperature ( \pm standard deviation) during 2003 and 2004 in Ballenas Channel and Bahía de los Ángeles. (a) Data collected in situ and (b) satellite data (http://oceancolor.gsfc.nasa.gov). Horizontal bars along the $x$ axis indicate the weeks when the search effort was carried out in the study area.

Figura 2. Temperatura superficial del mar media semanal ( \pm desviación estándar) durante 2003 y 2004 en el canal de Ballenas y la bahía de los Ángeles. (a) Datos recolectados in situ y (b) datos satelitales (http://oceancolor.gsfc.nasa.gov). Las barras horizontales a lo largo del eje $x$ indican las semanas cuando se realizó el esfuerzo de búsqueda en el área de estudio.

Satellite data underestimated sea-truth SST but showed a similar trend to that of in situ data, with higher SST in 2003 $\left(23.3 \pm 4.8^{\circ} \mathrm{C}\right)$ than in $2004\left(22.5 \pm 4.9^{\circ} \mathrm{C}\right)$, although there were no significant differences between years $\left(t_{88}=0.755\right.$, $P=0.45)$. This may be due to similar SST from June to September (fig. 2b). However, satellite data revealed a $1.0^{\circ} \mathrm{C}$ difference between March 2003 and 2004, and $1.6^{\circ} \mathrm{C}$ between October 2003 and 2004.

\section{Fin whale and euphausiid distribution}

The search effort for whales showed no significant differences between years for line transects $\left(t_{138}=0.77, P=0.44\right)$ $\left(t_{138}=0.77, P=0.44\right)$ y los muestreos no sistemáticos $\left(t_{138}=0.86, P=0.39\right)$ o para la combinación de ambos $\left(t_{138}=\right.$ $1.28, P=0.203)$. Por lo tanto, se combinaron los datos de ambos años para los análisis posteriores.

Las rorcuales se encontraron con mayor frecuencia al sur de $29.2^{\circ} \mathrm{N}$ y cerca de la costa de Baja California que en otras partes del canal de Ballenas (fig. 3). Se observaron principalmente en aguas al sur de la isla Coronado y desde la entrada oriental de bahía de los Ángeles hasta bahía Las Ánimas, cerca de la costa de Baja California. La abundancia relativa (IAR, ballenas $\mathrm{km}^{-1}$ ) no difirió significativamente entre aguas someras $(0-200 \mathrm{~m})$ y profundas $(201-1400 \mathrm{~m})$ en cada año (tabla 1); sin embargo, se observaron diferencias 


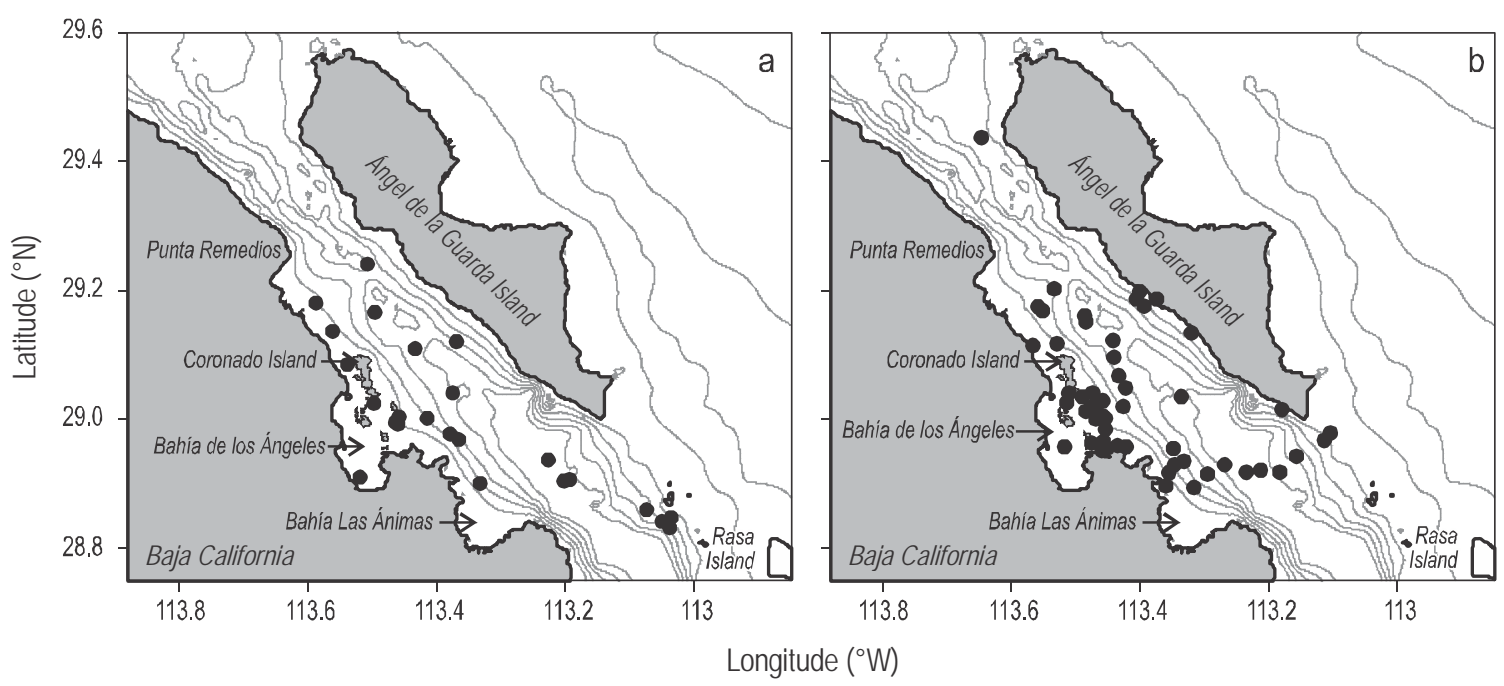

Figure 3. Fin whale (Balaenoptera physalus) sightings in (a) 2003 and (b) 2004. Isobath interval $=200 \mathrm{~m}$.

Figura 3. Avistamientos del rorcual común (Balaenoptera physalus) en (a) 2003 y (b) 2004. Intervalo de las isóbatas $=200 \mathrm{~m}$.

Table 1. Fin whale (Balaenoptera physalus) mean relative abundance index (RAI, number of whales per kilometer of search effort) in shallow (0-200 m) and deep (201-1400 m) waters of the Ballenas Channel and Bahía de los Ángeles during 2003 and 2004; $n=$ effort days. There were significant differences between years in shallow waters.

Tabla 1. Índice de abundancia relativa (RAI, número de ballenas por kilómetro de esfuerzo de búsqueda) del rorcual común (Balaenoptera physalus) en aguas someras (0-200 m de profundidad) y profundas (201-1400 m de profundidad) del canal de Ballenas y bahía de los Ángeles durante 2003 y 2004; $n=$ días de esfuerzo. Se observaron diferencias significativas entre años en aguas someras.

\begin{tabular}{|c|c|c|c|c|c|c|}
\hline Year & \multicolumn{3}{|c|}{ Shallow water } & \multicolumn{3}{|c|}{ Deep water } \\
\hline 2004 & 0.85 & $0.00-2.02$ & 49 & 0.11 & $0.00-0.25$ & 31 \\
\hline
\end{tabular}

and non-systematic surveys $\left(t_{138}=0.86, P=0.39\right)$ or for the combination of both $\left(t_{138}=1.28, P=0.203\right)$. Therefore, data from both years were pooled for further analyses.

Fin whales were more often found south of $29.2^{\circ} \mathrm{N}$ and near the Baja California coast than in other areas of the Ballenas Channel (fig. 3). They were mainly observed in waters south of Coronado Island and from the eastern entrance of Bahía de los Ángeles to Bahía Las Ánimas, near the coast of Baja California. Fin whale relative abundance (RAI, whales $\mathrm{km}^{-1}$ ) did not differ significantly between shallow $(0-200 \mathrm{~m})$ and deep waters $(201-1400 \mathrm{~m})$ within each survey year (table 1). However, there were significant differences in mean RAI between years in shallow waters (Mann-Whitney $U=684, P<0.001$; table 1) but not in deep waters.

Most of the euphausiids found in the samples were $N$. simplex, mainly in the third larval phase (calyptopis; fig. 4). This was expected because juvenile and adult euphausiids undergo diel vertical migrations (Lavaniegos 1996), so during the day only larvae stay at the surface. significativas en la abundancia relativa media entre años en el caso de aguas someras (Mann-Whitney $U=684, P<0.001$; tabla 1) pero no en el caso de aguas profundas.

La mayoría de los eufáusidos en las muestras resultaron ser $N$. simplex, principalmente en la tercera fase larvaria (caliptopis; fig. 4). Esto era de esperarse porque los eufáusidos juveniles y adultos realizan migraciones verticales diarias (Lavaniegos 1996), por lo que durante el día sólo las larvas permanecen en la superficie. No obstante, se supuso que las larvas indican la presencia de juveniles y adultos en la misma área con base en análisis previos de muestras recolectadas en el golfo de California en 1983 y 1984 (Lavaniegos et al. 1989). Se realizó una regresión de Pearson de estos datos entre las abundancias ( $\log$ ind $/ 1000 \mathrm{~m}^{3}$ ) de las larvas caliptopis y las postlarvas, que resultó ser significativa para el día y la noche $\left(R^{2}=0.30, P=0.001, n=33\right.$; fig. 5$)$. La ecuación resultante es:

$$
y=0.50 x+0.58
$$



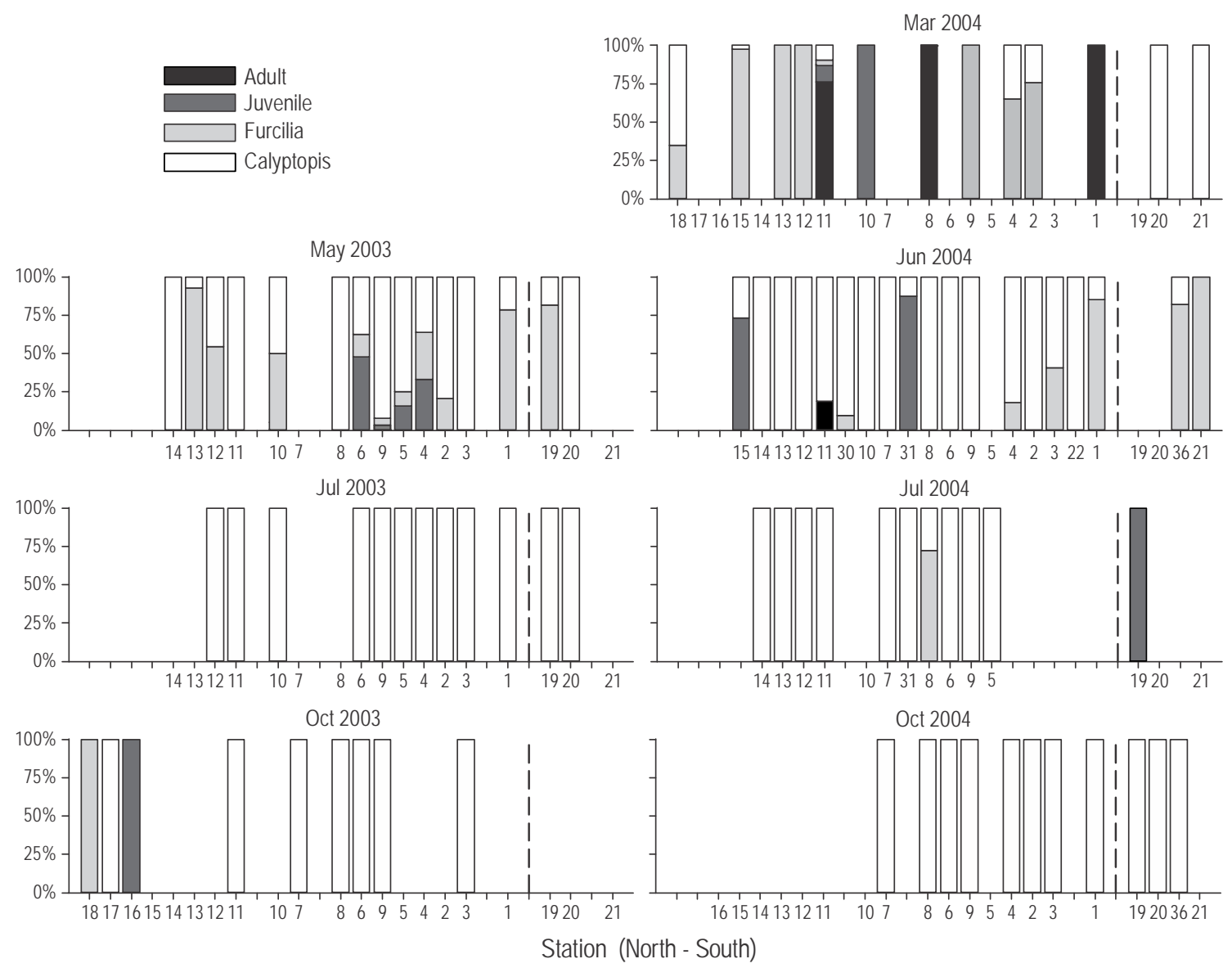

Figure 4. Relative biomass as organic carbon $\left(\mathrm{mg} \mathrm{C} \mathrm{m}^{-3}\right)$ of Nyctiphanes simplex life phases. Stations were ordered from north to south except those to the right of the dashed line, which correspond to Bahía de los Ángeles. Station numbers were omitted where no sample was collected.

Figura 4. Biomasa relativa como carbono orgánico $\left(\mathrm{mg} \mathrm{C} \mathrm{m}^{-3}\right)$ de las etapas de vida de Nyctiphanes simplex. Las estaciones se ordenaron de norte a sur excepto las del lado derecho de la línea discontinua, que corresponden a la bahía de los Ángeles. Se omitieron los números de las estaciones donde no se recolectó alguna muestra.

However, we assumed that the larvae are representative of juvenile and adult presence in the same area, based on previous analyses of samples collected in the Gulf of California in 1983 and 1984 (Lavaniegos et al. 1989). We carried out a Pearson regression of these data between abundances $\left(\log\right.$ ind $\left./ 1000 \mathrm{~m}^{3}\right)$ of calyptopis larvae and postlarvae, which was significant for both day and night $\left(R^{2}=0.30, P=0.001\right.$, $n=33$; fig. 5). The resulting equation is as follows:

$$
y=0.50 x+0.58
$$

Therefore, larvae at the surface during the day are representative of the presence of postlarvae (juveniles and adults). A Spearman correlation with data that were not transformed was also significant $\left(r_{S}=0.52, P=0.002\right)$.

We identified other euphausiid species (Nematoscelis difficilis, Euphausia distinguenda, Euphausia eximia), but
Por lo tanto, la presencia de larvas en la superficie durante el día es indicativo de la presencia de postlarvas (juveniles y adultos). Una correlación de Spearman con datos no transformados también fue significativa $\left(r_{S}=0.52, P=0.002\right)$.

Se identificaron otras especies de eufáusidos (Euphausia distinguenda, Euphausia eximia, Nematoscelis difficilis), pero sólo constituyeron el $0.1 \%$ del total de eufáusidos. Por lo tanto, de aquí en adelante, con eufáusidos nos referimos a N. simplex.

La abundancia media anual de eufáusidos fue menor para la bahía de los Ángeles (aguas someras) que para el canal de Ballenas (agua profundas) en ambos años (fig. 6). La comparación de las abundancias entre años no mostró diferencias significativas para aguas someras (Mann-Whitney $U=122$, $P=0.620)$ o profundas $(U=665, P=0.261)$, probablemente debido a la alta variabilidad de los datos (ver intervalos de confianza de $95 \%$ en la tabla 2). 


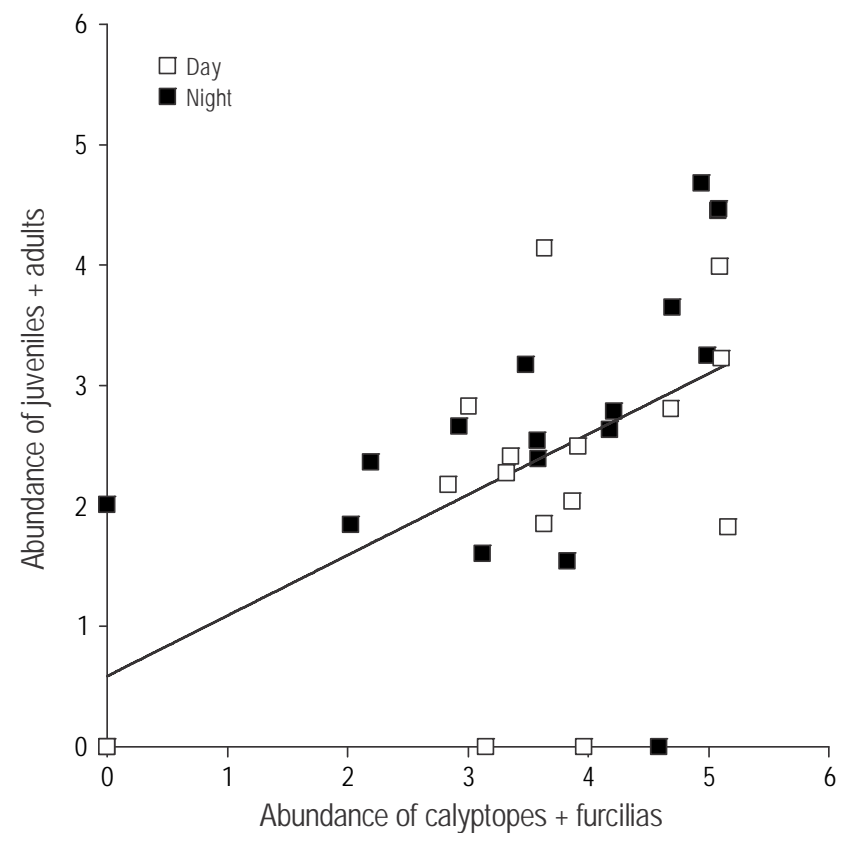

Figure 5. Regression of larval (calyptopes + furcilias) and postlarval (juveniles + adults) abundances $\left(\log\right.$ ind $/ 1000 \mathrm{~m}^{3}$ ) for diurnal and nocturnal samples collected in the Gulf of California in 1983 and 1984 (Lavaniegos et al. 1989).

Figura 5. Regresión de las abundancias $\left(\log\right.$ ind $\left./ 1000 \mathrm{~m}^{3}\right)$ de larvas (caliptopis + furcilia) y postlarvas (juveniles + adultos) en muestras diurnas y nocturnas recolectadas en el golfo de California en 1983 y 1984 (Lavaniegos et al. 1989).

they only made up $0.1 \%$ of the total euphausiids. Therefore, from now on we refer to $N$. simplex simply as euphausiids.

Annual mean abundance of euphausiids was lower in Bahía de los Ángeles (shallow waters) than in Ballenas Channel (deep waters) in both years (fig. 6). When comparing abundances between years there were no significant differences in shallow (Mann-Whitney $U=122, P=0.620$ ) or deep waters $(U=665, P=0.261)$, probably due to the high variability of data (see $95 \%$ confidence intervals in table 2 ).

\section{Temporal variation in abundance of fin whales and euphausiids}

Fin whales were significantly more abundant in 2004 than in 2003 (table 3; $U=782, P<0.001$ ). There were also significant differences in fin whale relative abundance from season to season within each year (2003: $H_{3,57}=10.99, P=0.01$; 2004: $\left.H_{3,70}=24.22, P<0.001\right)$. Changes in seasonal abundance were similar for both years: the RAI was lowest in October and highest in July (table 3).

There were no significant differences in euphausiid abundance between 2003 and 2004 (table 4; $U=1919, P=0.45$ ), with geometric means of 174 and $255 \mathrm{ind} / 1000 \mathrm{~m}^{3}$, respectively, for the whole region (table 4). However, there were seasonal differences in $2003\left(H_{2,54}=16, P<0.001\right)$, due to a

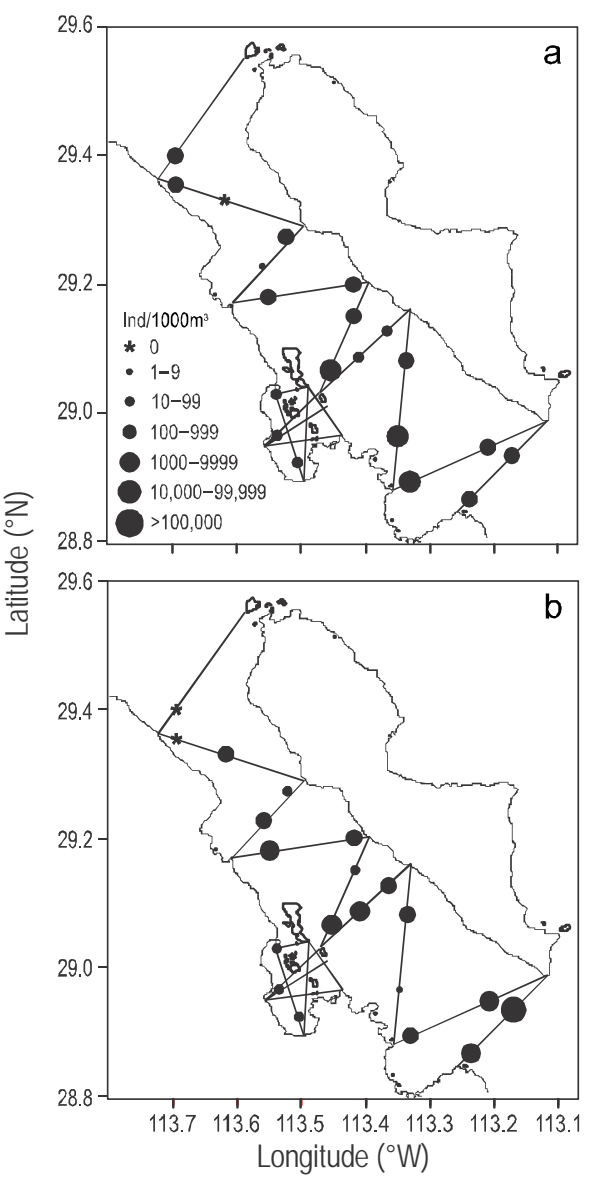

Figure 6. Distribution of annual mean abundance of euphausiids (Nyctiphanes simplex) during (a) 2003 and (b) 2004.

Figura 6. Distribución de la abundancia media anual de eufáusidos (Nyctiphanes simplex) durante (a) 2003 y (b) 2004.

\section{Variación temporal de la abundancia del rorcual común y eufáusidos}

La abundancia del rorcual común fue significativamente mayor en 2004 que en 2003 (tabla 3; $U=782, P<0.001$ ). También se observaron diferencias significativas en la abundancia relativa del rorcual común entre temporadas dentro de cada año (2003: $H_{3,57}=10.99, P=0.01 ; 2004: H_{3,70}=24.22$, $P<0.001)$. Los cambios en la abundancia estacional fueron similares para ambos años: el IAR fue menor en octubre y mayor en julio (tabla 3 ).

No se observaron diferencias significativas en la abundancia de eufáusidos entre 2003 y 2004 (tabla 4; $U=1919$, $P=0.45$ ), con medias geométricas de 174 y $255 \mathrm{ind} / 1000 \mathrm{~m}^{3}$, respectivamente, para toda la región (tabla 4). Sin embargo, se registraron diferencias estacionales en $2003\left(H_{2,54}=16\right.$, $P<0.001$ ), observándose una fuerte disminución de la abundancia de eufáusidos entre el periodo de transición de junio (frío-cálido) y la temporada cálida en el canal de Ballenas pero un aumento en la bahía de los Ángeles. Se observó una 
Table 2. Euphausiid (Nyctiphanes simplex) annual geometric mean abundance (ind/1000 $\mathrm{m}^{3}$ ) in shallow and deep waters of the Ballenas Channel and Bahía de los Ángeles during 2003 and 2004; $n=$ sampling stations (see fig. 1). Data for the 2004 cold season were excluded.

Tabla 2. Abundancia media geométrica anual (ind/1000 $\mathrm{m}^{3}$ ) de los eufáusidos (Nyctiphanes simplex) en aguas someras y profundas del canal de Ballenas y la bahía de los Ángeles durante 2003 y 2004; $n=$ estaciones de muestreo (ver fig. 1). Se excluyeron los datos para la temporada fría de 2004.

\begin{tabular}{cccccccc}
\hline & \multicolumn{3}{c}{ Shallow water } & & \multicolumn{3}{c}{ Deep water } \\
\cline { 2 - 3 } Year & $\begin{array}{c}\text { Abundance } \\
\left(\text { ind } / 1000 \mathrm{~m}^{3}\right)\end{array}$ & $95 \%$ confidence interval & $n$ & & $\begin{array}{c}\text { Abundance } \\
\left(\mathrm{ind} / 1000 \mathrm{~m}^{3}\right)\end{array}$ & $95 \%$ confidence interval & $n$ \\
\hline 2003 & 2.18 & $1.43-2.93$ & 16 & & 2.34 & $1.78-2.90$ & 38 \\
2004 & 2.10 & $1.15-3.05$ & 17 & & 2.74 & $2.18-3.30$ \\
\hline
\end{tabular}

Table 3. Fin whale (Balaenoptera physalus) mean relative abundance index (RAI, number of whales per hour of search effort) by year and by season in the Ballenas Channel and Bahía de los Ángeles during 2003 and 2004. There were significant differences between years and from one season to another within each year $(P<0.05)$.

Tabla 3. Índice de abundancia relativa (RAI, número de ballenas por hora de esfuerzo de búsqueda), por año y temporada, del rorcual común (Balaenoptera physalus) en el canal de Ballenas Channel y la bahía de los Ángeles durante 2003 y 2004. Se observaron diferencias significativas entre años y entre temporadas de cada año $(P<0.05)$.

\begin{tabular}{|c|c|c|c|c|}
\hline \multirow[b]{2}{*}{ Year } & \multirow[b]{2}{*}{ Season } & \multirow[b]{2}{*}{ Survey dates } & \multicolumn{2}{|r|}{ RAI } \\
\hline & & & Whales $\mathrm{h}^{-1}$ & $95 \%$ confidence interval \\
\hline \multirow[t]{4}{*}{2003} & Cold & $12 \mathrm{Mar}-10 \mathrm{Apr}$ & 0.20 & $-0.15-0.54$ \\
\hline & Cold-warm transition & 27 May-26 Jun & 0.20 & $-0.01-0.40$ \\
\hline & Warm & 11 Jul-4 Aug & 1.16 & $0.16-2.15$ \\
\hline & Late warm & 16 Oct-2 Dec & 0.09 & $-0.06-0.23$ \\
\hline Annual & & & 0.46 & $0.15-0.77$ \\
\hline \multirow[t]{4}{*}{2004} & Cold & 6-31 Mar & 2.16 & $1.11-3.21$ \\
\hline & Cold-warm transition & 3 Jun-1 Jul & 1.66 & $1.05-2.27$ \\
\hline & Warm & 2-30 Jul & 4.74 & $2.20-7.27$ \\
\hline & Late warm & $7-31$ Oct & 0.38 & $0.004-0.75$ \\
\hline Annual & & & 2.22 & $1.53-2.91$ \\
\hline
\end{tabular}

Table 4. Nyctiphanes simplex geometric mean abundance (ind/1000 $\mathrm{m}^{3}$ ) by year and by season in the Ballenas Channel and Bahía de los Ángeles during 2003 and 2004.

Tabla 4. Abundancia media geométrica (ind/1000 $\mathrm{m}^{3}$ ), por año y temporada, de Nyctiphanes simplex en el canal de Ballenas y la bahía de los Ángeles durante 2003 y 2004.

\begin{tabular}{|c|c|c|c|c|c|}
\hline Year & Season & Sampling dates & Ballenas Channel & Bahía de los Ángeles & Whole region \\
\hline \multirow[t]{4}{*}{2003} & Cold & - & - & - & - \\
\hline & Cold-warm transition & 27 May-2 Jun & 4198 & 53 & 1853 \\
\hline & Warm & 11-31 Jul & 288 & 1054 & 362 \\
\hline & Late warm & $16-22 \mathrm{Oct}$ & 17 & 6 & 15 \\
\hline Annual & & & 207 & 72 & 174 \\
\hline \multirow[t]{4}{*}{2004} & Cold & 6-19 Mar & 52 & 134 & 59 \\
\hline & Cold-warm transition & 3-20 Jun & 6610 & 60 & 2821 \\
\hline & Warm & 9-30 Jul & 540 & 7 & 221 \\
\hline & Late warm & $7-23$ Oct & 59 & 523 & 92 \\
\hline Annual & & & 324 & 87 & 255 \\
\hline
\end{tabular}


strong decrease observed from the cold-warm transition period to the warm season in Ballenas Channel, while euphausiids increased in Bahía de los Ángeles. A more dramatic and significant decrease was observed in the whole region between the warm and late warm seasons in 2003 $(U=95, P=0.01)$. Seasonal differences also occurred in $2004\left(H_{3,77}=12, P=0.006\right)$. Pairwise comparisons indicated that euphausiid abundance increased two orders of magnitude (table 4) from the cold to the cold-warm transition seasons $(U=103, P=0.001)$, but decreased again in the warm season $(U=83, P=0.02)$.

In order to analyze a possible correlation between whale and euphausiid abundance on a shorter time scale, data were grouped by weekly abundance. Fin whale relative abundance seemed to increase from May to July and then drastically decreased in October (fig. 7). Mean weekly abundance of euphausiids in 2003 showed high values in May and low variability from one week to another (fig. 8). In 2004, euphausiid abundance started to increase from March to April, reaching maximum values in June, while the weeks in October had the lowest values. During the last week of October a single tow collected a great amount of euphausiids, so this apparent increase in abundance should be taken with caution.

We found no statistical correlation between the weekly abundance of fin whales and euphausiids in 2003 (Spearman's $\left.r_{S}=0.079, P=0.754\right)$ or in $2004\left(r_{S}=0.126\right.$, $P=0.557)$. It is interesting to note that there seemed to be a lag of about four weeks between euphausiid and whale maximum abundance during both sampling years (end of May to end of July 2003, and June to end of July 2004; figs. 7, 8).

\section{DISCUSSION}

\section{Fin whale and euphausiid distribution}

Fin whale foraging occurs in regions with high biological productivity, often related to fronts, upwelling areas, and complex bottom topography (Laran et al. 2010, Santora et al. 2010). The Ballenas Channel and Bahía de los Ángeles region is such a region, where ocean dynamics (López et al. 2006) constantly provide nutrients to primary producers and, therefore, high biological productivity is observed year-round (Millán-Núñez and Yentsch 2000). A similar pattern has been observed in Monterey Bay, California, where blue whales forage on euphausiids (Thysanoessa spinifera and E. pacifica) in a very rich coastal upwelling ecosystem (Croll et al. 2005).

Even though fin whales were observed throughout the study area, they were recorded more frequently in shallow waters close to the Baja California coast and south of Coronado Island. There is a steep slope to the east of Coronado Island and south of the Bahía de los Ángeles archipelago (fig. 1). This bottom topography, combined with wind-induced currents and the vertical migration of disminución aún más significativa y dramática en toda la región entre la temporada cálida y la temporada cálida tardía en $2003(U=95, P=0.01)$. También se observaron diferencias estacionales en $2004\left(H_{3,77}=12, P=0.006\right)$. Las comparaciones pareadas indicaron que la abundancia de eufáusidos aumentó dos órdenes de magnitud (tabla 4) entre la temporada fría y el periodo de transición de junio $(U=103, P=0.001)$, pero disminuyó de nuevo en la temporada cálida $(U=83, P=0.02)$.

Para analizar una posible correlación entre la abundancia de rorcuales y eufáusidos a menor escala temporal, se agruparon los datos por abundancia semanal. La abundancia relativa del rorcual común aumentó de mayo a julio para luego disminuir drásticamente en octubre (fig. 7). La abundancia media semanal de eufáusidos en 2003 mostró valores altos en mayo y baja variabilidad entre semanas (fig. 8). En 2004, la abundancia de eufáusidos empezó a incrementar de marzo a abril hasta alcanzar valores máximos en junio; las semanas de octubre presentaron los valores más bajos. Durante la última semana de octubre, un solo arrastre recolectó una gran cantidad de eufáusidos, por lo que este aparente incremento de abundancia debe tomarse con precaución.

No se observó una correlación estadística entre la abundancia semanal de rorcuales y eufáusidos en $2003\left(r_{S}\right.$ de Spearman $=0.079, P=0.754)$ o en $2004\left(r_{S}=0.126, P=\right.$ 0.557). Es interesante notar que parece haber un desfase de alrededor de cuatro semanas entre la abundancia máxima de eufáusidos y rorcuales en ambos años (finales de mayo a finales de julio de 2003 y de junio a finales de julio de 2004; figs. 7, 8).

\section{DISCUSIÓN}

\section{Distribución del rorcual común y de los eufáusidos}

El rorcual común se alimenta en regiones con alta productividad biológica, frecuentemente asociada a frentes, zonas de surgencia y una topografía compleja del fondo (Laran et al. 2010, Santora et al. 2010). Tal es el caso de la región del canal de Ballenas y bahía de los Ángeles, donde la dinámica del océano (López et al. 2006) constantemente proporciona nutrientes a los productores primarios y se observa una alta productividad biológica a lo largo del año (Millán-Núñez y Yentsch 2000). Se ha observado un patrón similar en la bahía de Monterey, California, donde la ballena azul se alimenta de eufáusidos (Thysanoessa spinifera y E. pacifica) en un rico ecosistema de surgencia costera (Croll et al. 2005).

Si bien se observó el rorcual común en toda la zona de estudio, se registró con mayor frecuencia en aguas someras cerca de la costa de Baja California y al sur de la isla Coronado. Existe una pendiente abrupta al este de la isla Coronado y al sur del archipiélago de la bahía de los Ángeles (fig. 1). Esta topografía del fondo, junto con las corrientes generadas por el viento y la migración vertical de los eufáusidos (Lavaniegos 1996, Gómez-Gutiérrez et al. 2010, 
euphausiids (Lavaniegos 1996, Gómez-Gutiérrez et al. 2010, Tremblay et al. 2010), may contribute to the fact that euphausids concentrate there and are available as prey for whales (Ladrón de Guevara et al. 2008). Brinton and Townsend (1980) found that euphausiid abundance here and at other sites on the continental shelf of the Gulf of California was as high as 5000 ind/1000 $\mathrm{m}^{3}$ from February to June. These authors showed that even during the warmest month (August), the abundance of $N$. simplex remains high in the Midriff Islands region (where our study area is located), whereas it decreases in the rest of the Gulf of California. This pattern was also observed by Gómez-Gutiérrez et al. (2012).
Tremblay et al. 2010), puede contribuir al hecho de que los eufáusidos se agreguen ahí y estén disponibles como presas para los rorcuales (Ladrón de Guevara et al. 2008). Brinton y Townsend (1980) documentaron que aquí y en otros sitios de la plataforma continental del golfo de California la abundancia de eufáusidos puede ser de hasta 5000 ind $/ 1000 \mathrm{~m}^{3} \mathrm{de}$ febrero a junio. Estos autores mostraron que aun durante el mes más cálido (agosto), la abundancia de $N$. simplex permanece alta en la región de las grandes islas (donde se ubica nuestra área de estudio), mientras que disminuye en el resto del golfo de California. Este patrón también coincide con lo observado por Gómez-Gutiérrez et al. (2012).

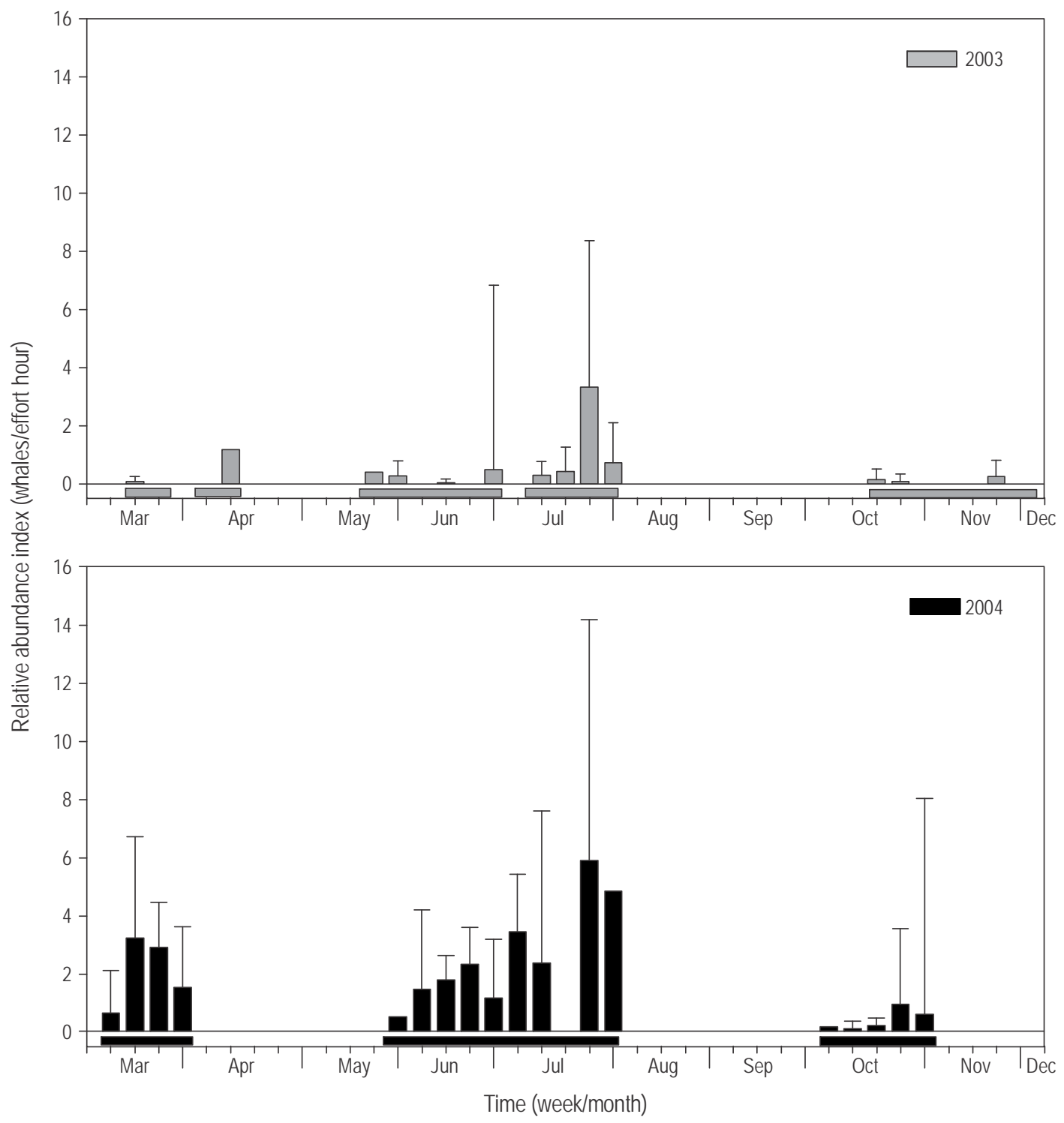

Figure 7. Fin whale (Balaenoptera physalus) weekly relative abundance (whales $\mathrm{h}^{-1}$ ) during 2003 and 2004 . Vertical bars are weekly means and $95 \%$ confidence intervals; horizontal bars along the $x$ axis indicate the weeks when the search effort was carried out.

Figura 7. Abundancia relativa semanal (ballenas $\mathrm{h}^{-1}$ ) del rorcual común (Balaenoptera physalus) durante 2003 y 2004. Las barras verticales son medias semanales e intervalos de confianza de 95\%; las barras horizontales a lo largo del eje $x$ indican las semanas cuando se realizó el esfuerzo de búsqueda. 
Daytime surface tows carried out in this study certainly underestimated the abundance of juvenile and adult euphausiids and even late furcilia stages due to the circadian vertical migration of euphausiids (Lavaniegos 1996, GómezGutiérrez et al. 2010). Juvenile and adult $N$. simplex are capable of descending to a depth of $300 \mathrm{~m}$ during the day but usually perform short vertical migrations $(150 \mathrm{~m})$, and larval stages increase vertical distance during their daily vertical migrations while growing (Lavaniegos 1996). Thus, calyptopis and early furcilia stages likely stay near the surface during the day and night. Even though data in this study are biased to calyptopes and small furcilias, their presence at the surface
Los arrastres superficiales realizados durante el día en este estudio subestimaron la abundancia de los eufáusidos juveniles y adultos e incluso los eufáusidos en estadio de furcilia tardía debido a su migración vertical circadiana (Lavaniegos 1996, Gómez-Gutiérrez et al. 2010). Los eufáusidos juveniles y adultos son capaces de descender hasta una profundidad de $300 \mathrm{~m}$ durante el día, aunque generalmente realizan migraciones verticales más cortas $(150 \mathrm{~m})$. Las etapas larvales aumentan su distancia vertical durante sus migraciones diarias conforme crecen (Lavaniegos 1996). Por lo tanto, los eufáusidos en estadios de caliptopis y furcilia temprana probablemente permanecen cerca de la superficie

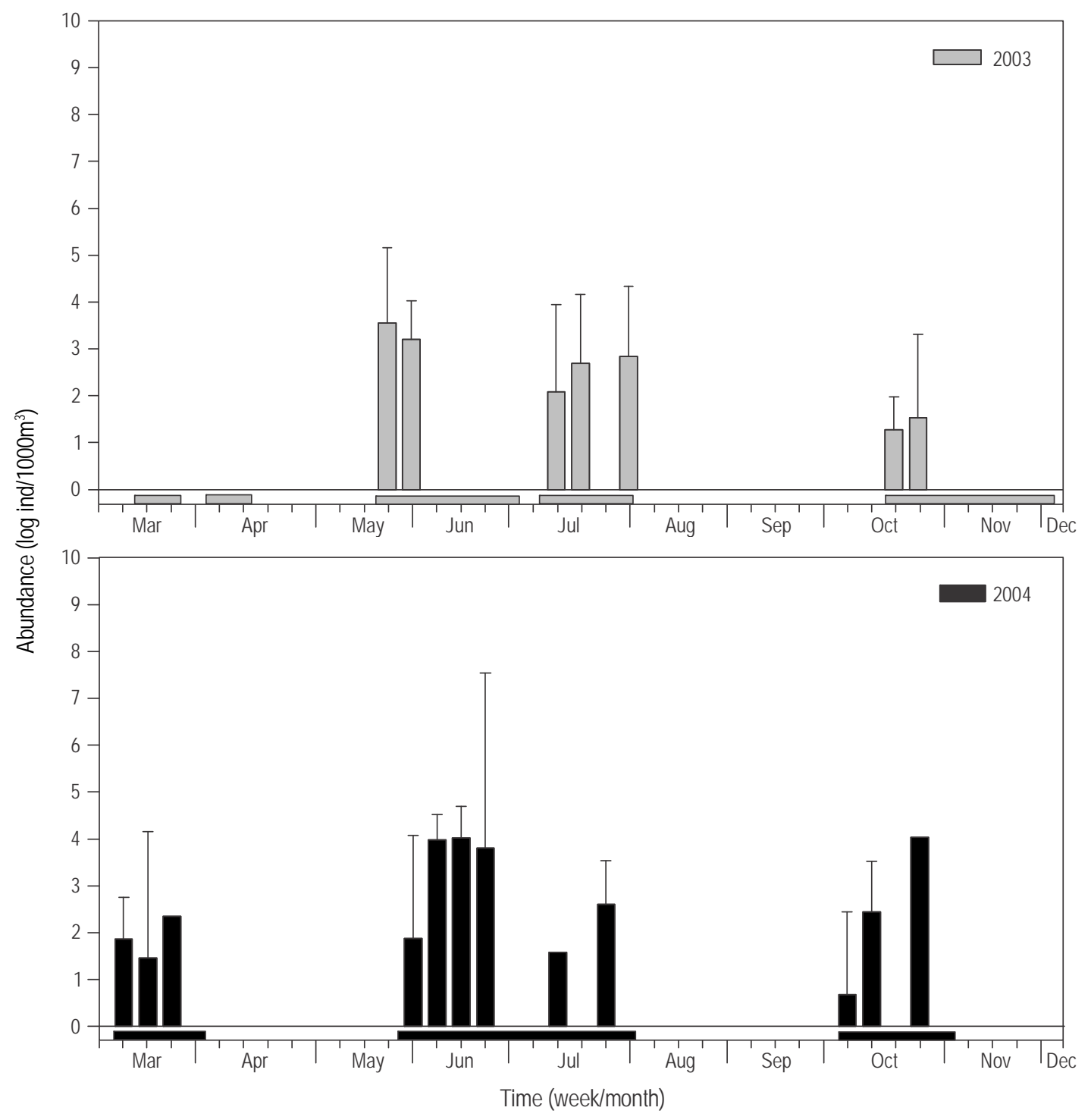

Figure 8. Euphausiid (Nyctiphanes simplex) weekly mean abundance (log ind/1000 $\mathrm{m}^{3}$ ) during 2003 and 2004 . Vertical bars are weekly means and $95 \%$ confidence intervals; horizontal bars along the $x$ axis indicate the weeks when the search effort was carried out. Data were log-transformed to calculate means.

Figura 8. Abundancia media semanal $\left(\log\right.$ ind $/ 1000 \mathrm{~m}^{3}$ ) de los eufáusidos (Nyctiphanes simplex) durante 2003 y 2004 . Las barras verticales son medias semanales e intervalos de confianza de 95\%; las barras horizontales a lo largo del eje $x$ indican las semanas cuando se realizó el esfuerzo de búsqueda. Los datos fueron transformados logarítmicamente para calcular las medias. 
all day long is a relatively good indicator of the presence and abundance of the juvenile and adult euphausiid population in the study area, as we confirmed in the correlation analysis of data obtained in 1983 and 1984 in the Gulf of California by Lavaniegos et al. (1989).

Undersampling in this study was inevitable due to the vertical migrations of euphausiids and also to their evasion of the net, since it is visible during the daylight hours. However, this is not necessarily the main reason for the lack of statistical correlation of weekly abundance between euphausiids and whales. Another problem with net tows is that they do not guarantee finding a correlation between whales and their prey because euphausiids form dense, heterogeneously distributed aggregations. For example, Brodie et al (1978) conducted zooplankton tows at a depth of $300 \mathrm{~m}$ off Nova Scotia as well as an analysis of whale stomach contents to find a positive statistical correlation between available and ingested prey. According to these authors, estimated available krill in the study area was not sufficient to sustain the whale population. Whales foraged on dense krill aggregations at depths that were possibly not sampled during net tows. Currently, a combination of expensive sampling methods is used to associate the presence of euphausiids and whales, including acoustic backscatter, zooplankton net tows, underwater videos, and telemetry (Croll et al. 1998, Fiedler et al. 1998, Friedlaender et al. 2009, Laidre et al. 2010). Moreover, mesoscale studies (hundreds of kilometers) tend to show clear spatial correlations between whales and their prey, as in Antarctic fin whales and Euphausia superba (Santora et al. 2010).

\section{Temporal variation in fin whale and euphausiid abundances}

In this study, the highest abundance of fin whales occurred during the warm season, as was also observed in the Mediterranean Sea from 2001 to 2004 (Laran et al. 2010). In the southwestern Gulf of California, fin whales were more abundant during the cold than during the warm season in 2004 (Alonso-Lozano 2014). We found that both euphausiids and fin whales had the lowest abundances during October 2003 and 2004 in our study area. This may be related to the increase in SST during the warm season and to temperatures remaining high throughout the season. Nutrients $\left(\mathrm{PO}_{4}, \mathrm{NO}_{3}\right.$, and $\left.\mathrm{Si}(\mathrm{OH})_{4}\right)$ are scarce due to intense biological activity (phytoplankton uptake) and stratification of the water column (Torres-Delgado et al. 2013). This may have had a negative effect on the reproduction and recruitment of $N$. simplex, particularly during 2003 (mean SST $24^{\circ} \mathrm{C}$ ). This species thrives in upwelling areas and although larvae may tolerate temperatures between 13 and $30^{\circ} \mathrm{C}$, the temperature range with highest larval abundances is between 17 and $20^{\circ} \mathrm{C}$ (Brinton and Townsend 1980). A study showed that $N$. simplex avoided the upper layer during the warm season, when temperature in the mixed layer was $22-29^{\circ} \mathrm{C}$ (Gómez-Gutiérrez et al. 2010). durante el día y la noche. A pesar de que los datos de este trabajo están sesgados hacia los estadios larvales (caliptopis y furcilia), su presencia en la superficie durante todo el día es un indicador relativamente bueno de la presencia y abundancia de eufáusidos juveniles y adultos en el área de estudio, como se comprobó con el análisis de correlación de los datos obtenidos en 1983 y 1984 en el golfo de California por Lavaniegos et al. (1989).

Una subestimación de los datos era inevitable debido a las migraciones verticales que realizan los eufáusidos así como a su evasión de la red, la cual es visible durante el día. No obstante, la falta de correlación estadística de la abundancia semanal entre los eufáusidos y rorcuales no necesariamente se debe sólo a esto. Otro problema con arrastres superficiales es que no garantizan encontrar una correlación entre las rorcuales y su presa porque los eufáusidos forman densas agregaciones que se distribuyen heterogéneamente. Por ejemplo, Brodie et al. (1978) realizaron arrastres de zooplancton a una profundidad de $300 \mathrm{~m}$ en frente de Nueva Escocia y un análisis del contenido estomacal de ballenas para encontrar una correlación estadística positiva entre las presas disponibles y las ingeridas. Según estos autores, el krill disponible en el área de estudio no era suficiente para mantener a la población de ballenas. Las ballenas se alimentaron de krill a profundidades que posiblemente no fueron muestreadas durante los arrastres. Actualmente, se emplean varios métodos costosos de muestreo para asociar la presencia de eufáusidos y ballenas, incluyendo retrodispersión acústica, arrastres de redes de zooplancton, videos subacuáticos y telemetría (Croll et al. 1998, Fiedler et al. 1998, Friedlaender et al. 2009, Laidre et al. 2010). Además, los estudios de mesoescala (cientos de kilómetros) tienden a mostrar claras correlaciones espaciales entre las ballenas y sus presas, como en el caso del rorcual en la Antártica y Euphausia superba (Santora et al. 2010).

\section{Variación temporal de la abundancia del rorcual común y eufáusidos}

En este estudio, la mayor abundancia del rorcual común se registró en la temporada cálida, como también se observó en la parte noroccidental del mar Mediterráneo entre 2001 y 2004 (Laran et al. 2010). En el golfo de California sudoccidental, el rorcual común fue más abundante durante la temporada fría que durante la cálida en 2004 (Alonso-Lozano 2014). En nuestra área de estudio, registramos la menor abundancia tanto de eufáusidos como de rorcuales en octubre de 2003 y 2004. Esto se puede atribuir al aumento de la TSM durante la temporada cálida y a que las temperaturas permanecieron altas durante toda la temporada. Los nutrientes $\left(\mathrm{PO}_{4}, \mathrm{NO}_{3}\right.$ y $\left.\mathrm{Si}(\mathrm{OH})_{4}\right)$ son escasos debido a la intensa actividad biológica (absorción por el fitoplancton) y la estratificación de la columna de agua (Torres-Delgado et al. 2013). Esto podría haber tenido un efecto negativo en la reproducción y reclutamiento de $N$. simplex, especialmente en 2003 
This coincides with the seasonal changes we recorded in 2003 and 2004 in the Ballenas Channel. Oxidative stress was also proposed as an ecophysiological factor in the decrease of $N$. simplex abundance during October due to shoaling of hypoxic conditions (Tremblay et al. 2010).

In our study, when the weekly variation in the abundance of euphausiids and fin whales was analyzed, there seemed to be a relationship at this temporal scale (figs. 7, 8). Both species were observed year-round in the Ballenas Channel and Bahía de los Ángeles, which confirms that fin whales remain at low latitudes when food is available (Aguilar 2009). The lack of a significant statistical correlation between the studied species was probably due to a lag in their maximum abundance. This seems plausible, since growth rates are slower and life cycles longer the higher up organisms are in the trophic web, so there is usually a lag in maximum productivity of primary and secondary consumers. In the upwelling region south of Australia, blue whales were observed foraging on the euphausiid Nyctiphanes australis approximately two months after the upwelling pulse and the highest chlorophyll $a$ concentration (Gill 2002).

In this study, fin whales were more abundant in 2004 than in 2003 in the Ballenas Channel and Bahía de los Ángeles region, but not euphausiids. Warmer SST was observed during September and October (fig. 2) suggesting a possible decrease in euphausiid productivity and, therefore, prey availability for whales. This apparent temperature anomaly in the Gulf of California seemed to be related to a weak El Niño event (McPhaden 2004).

In a previous study in the central Gulf of California, Lavaniegos et al. 1989 examined the influence of the 1983-1984 El Niño event on euphausiid populations. A difference in SST of $1-2^{\circ} \mathrm{C}$ was observed between spring 1983 (El Niño) and 1984. These authors suggested that water warming during 1983 had a negative effect on calyptopis recruitment of $N$. simplex, since the recorded abundance was three times lower than in 1984. Furthermore, the 1986-1987 and 1992-1993 El Niño events were probably also responsible for the absence of daytime surface swarms of $N$. simplex in the Gulf of California during those years (Gendron 1992). This coincides with our observations for whales, since the lowest abundance in our study occurred during 2003, the warmest of the two years. A lower number of daytime surface swarms were also found in the region during 2003 in the previous study by Ladrón de Guevara et al. (2008).

Changes in the distribution and occurrence of marine organisms during one year may occur depending on oceanographic features. Consequently, long time series are necessary to better understand the variation in the abundance of euphausiids and fin whales in the Ballenas Channel and Bahía de los Ángeles region. Nonetheless, in our two-year investigation we were able to establish that both euphausiids and fin whales are more abundant in shallow waters close to the Baja California coast and south of Coronado Island, probably in association with the bottom topography that promotes
(TSM media $24^{\circ} \mathrm{C}$ ). Esta especie prospera en zonas de surgencia y si bien las larvas pueden tolerar temperaturas entre 13 y $30^{\circ} \mathrm{C}$, la abundancia larval es mayor en un intervalo de temperatura de 17 a $20{ }^{\circ} \mathrm{C}$ (Brinton y Townsend 1980). Según Gómez-Gutiérrez et al. (2010), N. simplex evita la capa superior durante la temporada cálida, cuando la temperatura de la capa de mezcla varía de 22 a $29^{\circ} \mathrm{C}$. Esto coincide con los cambios estacionales registrados en el presente estudio en 2003 y 2004 en el canal de Ballenas. El estrés oxidativo también ha sido propuesto como un factor ecofisiológico de la disminución de la abundancia de $N$. simplex en octubre debido al afloramiento de condiciones hipóxicas (Tremblay et al. 2010).

En el presente estudio, el análisis de la variación semanal de la abundancia de eufáusidos y rorcuales mostró una posible relación a esta escala temporal (figs. 7, 8). Ambas especies se observaron durante todo el año en el canal de Ballenas y la bahía de los Ángeles, lo que confirma que los rorcuales permanecen en latitudes bajas cuando hay alimento disponible (Aguilar 2009). La falta de una correlación estadística significativa entre las dos especies estudiadas podría ser resultado de un desfase en su abundancia máxima. Esto es posible puesto que las tasas de crecimiento son más lentas y los ciclos de vida más largos entre más arriba se encuentren los organismos en la cadena trófica, por lo que normalmente hay un desfase en la productividad máxima de consumidores primarios y secundarios. En una zona de surgencia al sur de Australia, se observaron ballenas azules alimentándose del eufáusido Nyctiphanes australis aproximadamente dos meses después del pulso de surgencia y la mayor concentración de clorofila a (Gill 2002).

En la región del canal de Ballenas y la bahía de los Ángeles, el rorcual común fue más abundante en 2004 que en 2003, pero no los eufáusidos. La TSM fue mayor en septiembre y octubre (fig. 2), lo que sugiere una posible disminución de la productividad de los eufáusidos y, por lo tanto, de su disponibilidad como presa para los rorcuales. Esta aparente anomalía de temperatura en el golfo de California parece ser consecuencia de un evento débil de El Niño (McPhaden 2004).

En un estudio previo en el golfo de California, Lavaniegos et al. (1989) analizaron la influencia de El Niño 1983-1984 en las poblaciones de eufáusidos. Entre la primavera de 1983 (El Niño) y 1984, se registró una diferencia de TSM de $1-2{ }^{\circ} \mathrm{C}$. Estos autores sugieren que el calentamiento del agua en 1983 tuvo un efecto negativo en el reclutamiento larval (caliptopis) de $N$. simplex, puesto que la abundancia registrada fue tres veces menor que en 1984. Además, la ausencia de enjambres superficiales diurnos de $N$. simplex en el golfo de California durante 1986-1987 y 1992-1993 probablemente se relaciona con los eventos de El Niño de esos años (Gendron 1992). Esto coincide con nuestras observaciones, ya que la abundancia de rorcuales fue menor en 2003, el más cálido de los dos años. En el estudio previo de Ladrón de 
high phytoplankton concentration and, hence, euphausiid abundance. In addition, euphausiids and fin whales showed the lowest abundance during October of both years, probably related to high SST and low recruitment of $N$. simplex. There seemed to be a lag in the maximum abundance of predators and prey, since euphausiids were most abundant late during the cold-warm transition period and fin whales in July, during the warm season. Finally, regarding the hypothesis that the Ballenas Channel may be a refuge area for fin whales during El Niño years (Tershy et al. 1991), we propose that this is only true for strong El Niño events, because during our study we observed a higher abundance of fin whales during the colder year (2004) than during the warmer year (2003).

\section{ACKNOWLEDGMENTS}

Funding was provided by the International Community Foundation (California, USA), Fundación Internacional de la Comunidad (Tijuana, Mexico), CICESE, and Mexico's National Commission for Natural Protected Areas (CONANP). The research was conducted under SEMARNAT permits No. SGPA/DGVS/00510 dated 24/1/ 2003 and No. 1564 dated 13/3/2003. We thank the staff of the natural protected area Islas del Golfo de California, in particular I Fuentes and A Zavala, for their logistic and technical support. Enriqueta Velarde (Universidad Veracruzana) also provided logistic support. Many people contributed during the field work: L Barbosa, E Bravo, L del Toro, L Enríquez, F Lafarga, O Guzón, R Mendoza, E Morteo, S Rodríguez de la Gala, A Baez, Y Schramm, C Díaz, S Jaume, and S Nigenda. We appreciate the collaboration of J Urbán (Universidad Autónoma de Baja California Sur). Zooplankton sample analysis was carried out mainly by one of the authors (PLG), but was complemented by P García, I Ambriz-Arreola, I Navarrete, and C Navarro. We received advice on data analyses from E Solana, A Jaramillo, and M López. Previous versions of the manuscript were reviewed by L Rojas, J Urbán, J Gómez-Valdez, and G Gaxiola. Two anonymous reviewers helped to improve the paper.

\section{REFERENCES}

Acevedo-Gutiérrez A, Croll DA, Tershy BR. 2002. High feeding costs limit dive time in the largest whales. J. Exp. Biol. 205: 1747-1753.

Aguilar A. 2009. Fin whale (Balaenoptera physalus). In: Perrin WF, Würsig B, Thewissen JGM (eds.), Encyclopedia of Marine Mammals. 2nd ed. Academic Press, San Diego, California, pp. 433-437.

Alonso-Lozano L. 2014. Relación en la distribución y abundancia de misticetos, con algunos parámetros ambientales en la costa sur-occidental del Golfo de California (enero 2004-noviembre 2005). BSc thesis, Universidad Autónoma de Baja California Sur, La Paz, BCS, México, 67 pp.

Álvarez-Borrego S, Lara-Lara JR. 1991. The physical environment and primary productivity of the Gulf of California. In: Dauphin JP, Simoneit B (eds.), The Gulf and Peninsular Province of the Californias. American Association of Petroleum Geologists, Tulsa, Oklahoma, pp. 555-567.
Guevara et al. (2008), también se observó un menor número de enjambres superficiales diurnos en la región en 2003.

Los cambios anuales en la distribución y presencia de organismos marinos dependen de las condiciones oceanográficas. Por consiguiente, se requieren series de tiempo largas para entender mejor la variación de la abundancia de eufáusidos y el rorcual común en el canal de Ballenas y la bahía de los Ángeles. En nuestro estudio de dos años (2003 y 2004), fue posible establecer que tanto los eufáusidos como los rorcuales son más abundantes en aguas someras cerca de la costa de Baja California y al sur de la isla Coronado, probablemente debido a la topografía del fondo que promueve una alta concentración de fitoplancton y, por ende, de eufáusidos. La menor abundancia tanto de eufáusidos como de rorcuales se registró en octubre de ambos años, probablemente a causa de la alta TSM y al bajo reclutamiento de $N$. simplex. Parece haber un desfase en la máxima abundancia de presas y depredadores, siendo los eufáusidos más abundantes a finales del periodo de transición de junio (frío-cálido) y los rorcuales en julio, durante la temporada cálida. Finalmente, con respecto a la hipótesis de que el canal de Ballenas es una zona de refugio para rorcuales durante eventos de El Niño (Tershy et al. 1991), proponemos que esto sólo es válido en el caso de eventos fuertes, ya que durante este trabajo se observó una mayor abundancia de rorcuales durante el año más frío (2004) que durante el más cálido (2003).

\section{Agradecimientos}

Este trabajo fue apoyado por la Fundación Internacional de la Comunidad (Tijuana, México), International Community Foundation (California, EUA), CICESE y la Comisión Nacional de Áreas Naturales Protegidas (CONANP, México). El trabajo se realizó bajo los permisos de SEMARNAT No. SGPA/DGVS/00510 con fecha de 24/1/2003 y No. 1564 con fecha de 13/3/2003. Agradecemos al personal del área natural protegida Islas del Golfo de California, en particular a I Fuentes y A Zavala, su apoyo logístico y técnico. Enriqueta Velarde (Universidad Veracruzana) también proporcionó apoyo logístico. Las siguientes personas participaron en el trabajo de campo: L Barbosa, E Bravo, L del Toro, L Enríquez, F Lafarga, O Guzón, R Mendoza, E Morteo, S Rodríguez de la Gala, A Baez, Y Schramm, C Díaz, S Jaume y S Nigenda. El análisis de zooplancton fue realizado principalmente por uno de los autores (PLG), con apoyo de P García, I Ambriz-Arreola, I Navarrete y C Navarro. Agradecemos a J Urbán (Universidad Autónoma de Baja California Sur) su colaboración; a E Solana, A Jaramillo y M López su asesoramiento en los análisis de datos; y a L Rojas, J Urbán, J Gómez-Valdez y G Gaxiola sus revisiones de versiones anteriores del manuscrito. Los comentarios de dos revisores anónimos ayudaron a mejorar el artículo.

Traducido al español por Christine Harris. 
Álvarez-Molina LL, Álvarez-Borrego S, Lara-Lara JR, Marinone SG. 2013. Annual and semiannual variations of phytoplankton biomass and production in the central Gulf of California estimated from satellite data $=$ Variaciones anual y semianual de la biomasa y producción fitoplanctónica en el golfo de California central estimadas de datos de satélite. Cienc. Mar. 39: 217-230.

http://dx.doi.org/10.7773/cm.v39i2.2189

Barlow J, Forney KA. 2007. Abundance and population density of cetaceans in the California Current ecosystem. Fish. Bull. 105: 509-526.

Boden BP. 1951. The egg and larval stages of Nyctiphanes simplex, a euphausiid crustacean from California. Proc. Zool. Soc. Lond. 121: 515-527.

Brinton E, Townsend AW. 1980. Euphausiids in the Gulf of California: the 1957 cruises. CalCOFI Rep. 21: 211-236.

Brodie PF, Sameoto DD, Sheldon RW. 1978. Population densities of euphausiids off Nova Scotia as indicated by net samples, whale stomach contents, and sonar. Limnol. Oceanogr. 23: 1264-1267.

Buckland ST, Anderson DR, Burnham KP, Laake JL, Borchers DL, Thomas L. 2001. Introduction to Distance Sampling: Estimating Abundance of Biological Populations. Oxford University Press, Oxford, $431 \mathrm{pp}$.

Croll DA, Tershy BR, Hewitt RP, Demer DA, Fiedler PC, Smith SE, Armstrong W, Popp JM, Kiekhefer T, Lopez VR, UrbánRamírez J, Gendron D. 1998. An integrated approach to the foraging ecology of marine birds and mammals. Deep-Sea Res. (II) 45: 1353-1371.

Croll DA, Marinovic B, Benson S, Chávez FP, Black N, Ternullo R, Tershy BR. 2005. From wind to whales: Trophic links in a coastal upwelling system. Mar. Ecol. Prog. Ser. 289: 117-130.

Croll DA, Tershy BR, Newton KM. 2009. Filter feeding. In: Perrin W, Würsig B, Thewissen J (eds.), Encyclopedia of Marine Mammals. 2nd ed. Academic Press, San Diego, pp. 429-433.

Del-Ángel-Rodríguez J. 1997. Hábitos alimentarios y distribución espacio-temporal de los rorcuales común (Balaenoptera physalus) y azul (Balaenoptera musculus) en la Bahía de la Paz, Baja California Sur [Foraging habits and spatial-temporal distribution of fin whales (Balaenoptera physalus) and blue whales (Balaenoptera musculus) in La Paz Bay, Baja California Sur]. MSc thesis, Centro Interdisciplinario de Ciencias Marinas, Instituto Politécnico Nacional, La Paz, BCS, México, 68 pp.

Enríquez-Paredes LM. 1996. Ocurrencia, movimientos, estructura social y tamaño de las agregaciones de rorcual común (Balaenoptera physalus) en el Golfo de California, México [Occurrence, movements, social structure and size of aggregations of the fin whale (Balaenoptera physalus) in the Gulf of California, Mexico]. BSc thesis, Universidad Autónoma de Baja California Sur, La Paz, BCS, México. 59 pp.

Escalante F, Valdez-Holguín JE, Álvarez-Borrego S, Lara-Lara JR. 2013. Temporal and spatial variation of sea surface temperature, chlorophyll $a$, and primary productivity in the Gulf of California $=$ Variación temporal y espacial de temperatura superficial del mar, clorofila $a$ y productividad primaria en el golfo de California. Cienc. Mar. 39: 203-215. http://dx.doi.org/10.7773/cm.v39i2.2233

Fiedler P, Barlow J, Gerrodette T. 1998. Dolphin prey abundance determined from acoustic backscatter data in eastern Pacific surveys. Fish. Bull. 96: 237-247.

Flores-Ramírez S, Urbán-Ramírez J, Villarreal-Chávez G, VallesJiménez R. 1996. Cambios espaciales y temporales de la estructura comunitaria de los cetáceos en bahía de la Paz, BCS, México (1988-1991) = Spatial and temporal changes in the cetacean community structure at Bahía de La Paz, BCS, Mexico, 1988-1991). Cienc. Mar. 22: 151-173.
Friedlaender AS, Hazen EL, Nowacek DP, Halpin PN, Ware C, Weinrich MT, Hurst T, Wiley D. 2009. Diel changes in humpback whale Megaptera novaeangliae feeding behavior in response to sand lance Ammodytes spp. behavior and distribution. Mar. Ecol. Prog. Ser. 395: 91-100. http://dx.doi.org/10.3354/meps08003

Gendron, D. 1992. Population structure of daytime surface swarms of Nyctiphanes simplex (Crustacea: Euphausiacea) in the Gulf of California, Mexico. Mar. Ecol. Prog. Ser. 87: 1-6.

Gill PC. 2002. A blue whale (Balaenoptera musculus) feeding ground in a southern Australian coastal upwelling zone. J. Cetacean Res. Manage. 4: 179-184.

Goldbogen JA, Pyenson ND, Shadwick RE. 2007. Big gulps require high drag for fin whale lunge feeding. Mar. Ecol. Prog. Ser. 349: 289-301. http://dx.doi.org/10.3354/meps07066

Gómez-Gutiérrez J, Tremblay N, Martínez-Gómez S, Robinson DJ, Del-Ángel-Rodríguez J, Rodríguez-Jaramillo C, ZavalaHernández C. 2010. Biology of the subtropical sac-spawning euphausiid Nyctiphanes simplex in the northwestern seas of Mexico: Vertical and horizontal distribution patterns and seasonal variability of brood size. Deep-Sea Res. (II) 57: $606-615$. http://dx.doi.org/10.1016/j.dsr2.2009.10.010

Gómez-Gutiérrez J, Martínez-Gómez S, Robinson CJ. 2012. Seasonal growth, molt, and egg production rates of Nyctiphanes simplex (Crustacea: Euphausiacea) juveniles and adults in the Gulf of California. Mar. Ecol. Prog. Ser. 455: 173-194. http://dx.doi.org/10.3354/meps09631

Hidalgo-González RM, Álvarez-Borrego S. 2004. Total and new production in the Gulf of California estimated from ocean color data from the satellite sensor SeaWIFS. Deep-Sea Res (II) 51: 739-752. http://dx.doi.org/10.1016/j.dsr2.2004.05.006

Jaume-Schinkel, S. 2004. Hábitos alimentarios del rorcual común Balaenoptera physalus en el Golfo de California mediante el uso de isótopos estables de nitrógeno y carbono [Foraging habits of the fin whale Balaenoptera physalus in the Gulf of California from stable isotopes of nitrogen and carbon]. MSc thesis, Centro Interdisciplinario de Ciencias Marinas, Instituto Politécnico Nacional, La Paz, BCS, México, 64 pp.

Kawamura A. 1982. Food habits and prey distributions of the rorqual species in the North Pacific Ocean. Sci. Rep. Whales Res. Inst. 34: 59-91.

Ladrón de Guevara P, Lavaniegos BE, Heckel G. 2008. Fin whales (Balaenoptera physalus) foraging on daytime surface swarms of the euphausiid Nyctiphanes simplex in Ballenas Channel, Gulf of California, Mexico. J. Mammal. 89: 559-566.

Laidre KL, Heide-Jorgensen MP, Heagerty P, Cossio A, Bergström B, Simon M. 2010. Spatial associations between large baleen whales and their prey in West Greenland. Mar. Ecol. Prog. Ser. 402: 269-284. http://dx.doi.org/10.3354/meps08423

Laran S, Joiries C, Gannier A, Kenney RD. 2010. Seasonal estimates of densities and predation rates of cetaceans in the Ligurian Sea, northwestern Mediterranean Sea: An initial examination. J. Cetacean Res. Manage. 11: 31-40.

Lavaniegos BE. 1996. Vertical distribution of euphausiid life stages in waters adjacent to Baja California. Fish. Bull. 94: 300-312.

Lavaniegos BE, Lara-Lara JR, Brinton E. 1989. Effects of the 1982-83 El Niño event on the Euphausiid populations of the Gulf of California. CalCOFI Rep. 30: 73-87.

López M, Candela J, Argote ML. 2006. Why does the Ballenas Channel have the coldest SST in the Gulf of California? Geophys. Res. Lett. 33: 1-5.

http://dx.doi.org/10.1029/2006GL025908 
Macías-Zamora JV, Castro-Morales K, Burke RA, López-Mariscal M. 2013. Dissolved methane in the sills region of the Gulf of California $=$ Metano disuelto en la región de umbrales del golfo de California. Cienc. Mar. 39: 119-135. http://dx.doi.org/10.7773/cm.v39i2.2232

McPhaden, MJ. 2004. Evolution of the 2002-2003 El Niño. Bull. Am. Meteorol. Soc. 85: 677-695. htp://dx.doi.org/10.1175/BAMS-85-5-677

Millán-Núñez E, Yentsch CM. 2000. El Canal de Ballenas, Baja California, como ambiente favorable para el desarrollo del fitoplancton [The Ballenas Channel, Baja California, a favorable environment for the development of phytoplankton]. Hidrobiológica 10: 91-100.

Neave HR, Worthington PL. 1988. Distribution-free Tests. Unwin Hyman, London, $430 \mathrm{pp}$.

Ross RM. 1982. Energetics of Euphausia pacifica. I. Effects of body carbon and nitrogen and temperature on measured and predicted production. Mar. Biol. 68: 1-13.

Santora JA, Reiss CS, Loeb VJ, Veit RR. 2010. Spatial association between hotspots of baleen whales and demographic patterns of Antarctic krill Euphausia superba suggests size-dependent predation. Mar. Ecol. Prog. Ser. 405: 255-269. http://dx.doi.org/10.3354/meps08513

Tershy BR, Breese D, Alvarez-Borrego S. 1991. Increase in cetacean and seabird numbers in the Canal de Ballenas during an El Niño-Southern Oscillation event. Mar. Ecol. Prog. Ser. 69: 299-302.
Tershy BR, Acevedo-Gutiérrez A, Breese D, Strong C. 1993. Diet and feeding behavior of fin and Bryde's whales in the central Gulf of California, Mexico. Rev. Inv. Cient. Univ. Autón. Baja Calif. Sur 1: 31-38.

Torres-Delgado EV, Delgadillo-Hinojosa F, Camacho-Ibar VF, Huerta-Díaz MÁ, Segovia-Zavala JA, Hernández-Ayón JM, Galindo-Bect S. 2013. Wintertime enrichment of inorganic nutrients in the Ballenas Channel, Gulf of California = Enriquecimiento invernal de nutrientes inorgánicos en el canal de Ballenas, golfo de California. Cienc. Mar. 39: 165-182. http://dx.doi.org/10.7773/cm.v39i2.2236

Tremblay N, Gómez-Gutiérrez J, Zenteno-Savín T, Robinson DJ, Sánchez-Velasco L. 2010. Role of oxidative stress in seasonal and daily vertical migration of three krill species in the Gulf of California. Limnol. Oceanogr. 55: 2570-2584. http://dx.doi.org/10.4319/1o.2010.55.6.2570

Urbán-Ramírez J, Rojas-Bracho L, Guerrero-Ruiz M, JaramilloLegorreta A, Findley LT. 2005. Cetacean diversity and conservation in the Gulf of California. In: Cartron JE, Ceballos G, Felger RS (eds.), Biodiversity, Ecosystems, and Conservation in Northern Mexico. Oxford University Press, New York, pp. 276-297.

Vidal O, Findley L, Leatherwood S. 1993. Annotated checklist of the marine mammals of the Gulf of California. Proc. S. Diego Soc. Nat. Hist. 28: 1-16.

\section{Received November 2014, accepted April 2015.}

